\title{
Equilibrium and Formation/Dissociation Kinetics of some Lanthanide(III)-PCTA complexes
}

\author{
Gyula Tircsó\#, Zoltán Kovács@,§, and A. Dean Sherry\#,§,†, \\ \# Department of Chemistry, University of Texas at Dallas, P.O. Box 830660, Richardson, Texas, 75080 \\ $\S$ Advanced Imaging Research Center, University of Texas Southwestern Medical Center, 5323 Harry Hines \\ Boulevard, Dallas, Texas, 75390 \\ $\dagger$ Department of Radiology, University of Texas Southwestern Medical Center, 5323 Harry Hines Boulevard, \\ Dallas, Texas, 75390
}

@ Macrocyclics, 2110 Research Row, Suite 425, Dallas, Texas, 75235

\section{Abstract}

The protonation constants $\left(K_{i}^{H}\right)$ of 3,6,9,15-tetraazabicyclo[9.3.1]pentadeca-1(15),11,13-

triene-3,6,9,-triacetic acid (PCTA) and stability constants of complexes formed between this pyridine containing macrocycle and several different metal ions have been determined in $1.0 \mathrm{M} \mathrm{KCl}, 25^{\circ} \mathrm{C}$ and compared to previous literature values. The first protonation constant was found to be 0.5-0.6 $\log$ units higher than the value reported previously and a total five protonation steps were detected $\left(\log K_{i}^{H}=11.36,7.35,3.83,2.12\right.$ and 1.29). The stability constants of complexes formed between PCTA and $\mathrm{Mg}^{2+}, \mathrm{Ca}^{2+}, \mathrm{Cu}^{2+}$ and $\mathrm{Zn}^{2+}$ were also somewhat higher than those previously reported but this difference could be largely attributed to the higher first protonation constant of the ligand. Stability constants of complexes formed between PCTA and the $\mathrm{Ln}^{3+}$ series of ions and $\mathrm{Y}^{3+}$ were determined by using an "out-of-cell" potentiometric method. These values ranged from $\log K=18.15$ for $\mathrm{Ce}$ (PCTA) to $\log K=20.63$ for $\mathrm{Yb}$ (PCTA), increasing along the lanthanide series in proportion to decreasing $\mathrm{Ln}^{3+}$ cation size. The rates of complex formation for $\mathrm{Ce}(\mathrm{PCTA}), \mathrm{Eu}(\mathrm{PCTA}), \mathrm{Y}$ (PCTA) and $\mathrm{Yb}(\mathrm{PCTA})$ were followed by conventional UV-VIS spectroscopy in the $\mathrm{pH}$ range $\mathrm{pH}=3.5$ - 4.4. First order rate constants (saturation kinetics) obtained for different ligand / metal ion ratios were consistent with rapid formation of a diprotonated intermediate, $\mathrm{Ln}\left(\mathrm{H}_{2} \mathrm{PCTA}\right)^{2+}$. The stabilities of the intermediates as determined from the kinetic data were 2.81, 3.12, 2.97 and $2.69 \log K$ units for $\mathrm{Ce}\left(\mathrm{H}_{2} \mathrm{PCTA}\right), \mathrm{Eu}\left(\mathrm{H}_{2} \mathrm{PCTA}\right), \mathrm{Y}\left(\mathrm{H}_{2} \mathrm{PCTA}\right)$ and $\mathrm{Yb}\left(\mathrm{H}_{2} \mathrm{PCTA}\right)$, respectively. Rearrangement of these intermediates to the fully chelated complexes was the rate determining step and the rate constant $\left(k_{r}\right)$ for this process was found to be inversely proportional to the proton concentration. The formation rates $\left(k_{O H}\right)$ increased with a decrease in lanthanide ion size $\left(9.68 \times 10^{7} \mathrm{M}^{-1} \mathrm{~s}^{-1}, 1.74 \times 10^{8} \mathrm{M}^{-1} \mathrm{~s}^{-1}\right.$, $1.13 \times 10^{8} \mathrm{M}^{-1} \mathrm{~s}^{-1}$ and $1.11 \times 10^{9} \mathrm{M}^{-1} \mathrm{~s}^{-1}$ for $\mathrm{Ce}(\mathrm{PCTA}), \mathrm{Eu}(\mathrm{PCTA}), \mathrm{Y}(\mathrm{PCTA})$ and $\mathrm{Yb}(\mathrm{PCTA})$, respectively). These data indicate that the $\mathrm{Ln}(\mathrm{PCTA})$ complexes exhibit the fastest formation rates among all lanthanide macrocyclic ligand complexes studied to date. The acid catalyzed dissociation rates $\left(k_{1}\right)$ varied with cation from $9.61 \times 10^{-4} \mathrm{M}^{-1} \mathrm{~s}^{-1}, 5.08 \times 10^{-4} \mathrm{M}^{-1} \mathrm{~s}^{-1}, 1.07 \times 10^{-3} \mathrm{M}^{-1} \mathrm{~s}^{-1}$ and $2.80 \times 10^{-4} \mathrm{M}^{-1} \mathrm{~s}^{-1}$ for $\mathrm{Ce}(\mathrm{PCTA}), \mathrm{Eu}(\mathrm{PCTA}), \mathrm{Y}(\mathrm{PCTA})$ and $\mathrm{Yb}(\mathrm{PCTA})$, respectively.

\footnotetext{
*Author to whom correspondence should be addressed. Phone: 214-645-2730, E-mail: sherry@utdallas.edu or dean.sherry@utsouthwestern.edu.
} 


\section{Introduction}

Recent biomedical applications of lanthanide complexes has catalyzed a growing interest in the synthesis and evaluation of new functionalized open chain and macrocyclic ligands that form highly stable and kinetically inert complexes with various lanthanide ions $\left(\operatorname{Ln}^{3+}\right)$. The interest in paramagnetic and radioactive metal ions is largely driven by advances in magnetic resonance imaging (MRI) contrast agents (mostly $\mathrm{Gd}^{3+}$ complexes), nuclear medicine diagnostic agents (PET isotopes and $\gamma$-emitters such as ${ }^{67} \mathrm{Ga}^{3+},{ }^{111} \mathrm{In}^{3+}$ or ${ }^{169} \mathrm{Yb}^{3+}$ ) and therapeutic radiopharmaceuticals ( $\beta$ emitters such as ${ }^{90} \mathrm{Y}^{3+},{ }^{177} \mathrm{Lu}^{3+},{ }^{153} \mathrm{Sm}^{3+},{ }^{166} \mathrm{Ho}^{3+}$ or ${ }^{149} \mathrm{Pm}^{3+}$ ). ${ }^{1}$ Four $\mathrm{Gd}^{3+}$ complexes (two based upon DTPA and two based upon DOTA) have been used successfully as clinical MRI contrast agents for many years. ${ }^{2}$ Macrocyclic ligands like DOTA have some advantages over acyclic ligands like DTPA for certain applications because the rigidity of the macrocyclic ring adds to the thermodynamic stability and kinetic inertness of the resulting complexes. The linear and macrocyclic-based ligands exhibit markedly different formation kinetics as well. Macrocyclic ligands tend to form metal ion complexes much more slowly, ${ }^{3}$ a significant disadvantage when preparing therapeutic metalbased drugs involving short-lived radionuclides.

The development of novel ${ }^{90} \mathrm{Y}^{3+}$-labeled monoclonal antibodies and other therapeutic agents has stimulated interest in discovery of new yttrium complexes that have more favorable formation kinetics and yet remain inert toward dissociation. ${ }^{90} \mathrm{Y}^{3+}$ is an attractive isotope for radio-immunotherapy due to its favorable emission energy and long half-life $\left(t^{1} / 2=64 \mathrm{~h}\right)$. Since the ionic radii, oxidation state, and coordination chemistry of $\mathrm{Y}^{3+}$ and the $\mathrm{Ln}^{3+}$ ions are similar, the same type of ligands can be used for these ions. ${ }^{1}$ It is important to emphasize that kinetic inertness of the complexes plays a crucial role in determining the amount of radioactive ion released in vivo. Even though the thermodynamic stability of DTPA-based ligands with ${ }^{90} \mathrm{Y}^{3+}$ are satisfactorily high, they are also more kinetically labile than required for some applications. Any ${ }^{90} \mathrm{Y}^{3+}$ or radio-lanthanide ions released in vivo tends to accumulate in bone and can result in high radiation doses to bone marrow. ${ }^{4}$ Thus, the general requirements for $\mathrm{Ln}^{3+}$ or $\mathrm{Y}^{3+}$ complexes for therapeutic applications include a satisfactory thermodynamic stability and kinetic inertness and rapid complex formation rates for those radio-isotopes having short life-times.

A large number of 9- to 14-membered tri- or tetra-azamacrocycles with three to four carboxylate-containing side arms have been examined. The formation rates of the $\mathrm{Ln}^{3+}$ complexes is typically slow and, on the basis of kinetic data (saturation kinetics), the existence of stable di- or monoprotonated complexes is often observed. ${ }^{5-14}$ Protonated intermediates of $\mathrm{Ce}\left(\mathrm{H}_{2} \text { DOTA }\right)^{+}$and $\mathrm{Eu}\left(\mathrm{H}_{2} \text { DOTA }\right)^{+}$have been directly detected by UV-VIS, ${ }^{7-9}$

luminescence ${ }^{12}$ and NMR spectroscopy. ${ }^{14}$ The synthesis of the pyridine-containing 12 membered tetraazatriacetate ligand, 3,6,9,15-tetraazabicyclo[9.3.1]pentadeca-1(15),11,13triene-3,6,9,-triacetic acid ( $\mathrm{H}_{3}$ PCTA) has been described previously. ${ }^{15-18}$ This ligand has some attractive features for use in biomedicine including the presence of an aromatic chromophore that acts as an antenna for $\mathrm{Eu}^{3+}$ and $\mathrm{Tb}^{3+}$ luminescence and a high water relaxivity (q=2 complex) for the $\mathrm{Gd}^{3+}$ complex. ${ }^{16,19-21}$ Complexes of ${ }^{67} \mathrm{Ga}$ (III) ${ }^{68} \mathrm{Ga}$ (III) or ${ }^{111} \mathrm{In}$ (III) ions with PCTA have been suggested as radio-pharmaceuticals in radioimmunoscintigraphy and in positron emission tomography 22 based on the calculated pM and low osmolality values. These data compare favorably to the $\mathrm{pM}$ values for DOTA complexes at physiological pH. ${ }^{23}$ The stabilities of PCTA complexes with $\mathrm{Mg}^{2+}, \mathrm{Ca}^{2+}, \mathrm{Zn}^{2+}, \mathrm{Cu}^{2+}, \mathrm{Eu}^{3+}$ and $\mathrm{Gd}^{3+}$ have been reported, $16,19,23-25$ but neither detailed thermodynamics nor formation/ dissociation kinetics of the Ln(PCTA) complexes have been reported in detail.

The objective of the study was to determine the stability constants for the series of $\operatorname{Ln}$ (PCTA) complexes and compare those to the stability of the complexes formed with the structurally 
similar macrocyclic ligands, NOTA (1,4,7-triazacyclononane-N, $\mathrm{N}^{\prime}, \mathrm{N}^{\prime \prime}$-triacetate), DO3A (1,4,7,10-tetraazacyclododecane-1,4,7,-triacetic acid), DOTA, TRITA $(1,4,7,10$ tetraazacyclotridecane- $\mathrm{N}, \mathrm{N}^{\prime}, \mathrm{N}^{\prime \prime} \mathrm{N}^{\prime \prime \prime}$-tetracetate), and TETA $(1,4,8,11$ tetraazacyclotetradecane- $\mathrm{N}, \mathrm{N}^{\prime}, \mathrm{N}^{\prime \prime} \mathrm{N}^{\prime \prime}$-tetracetate). The kinetics of $\mathrm{Ln}(\mathrm{PCTA})$ complex formation and acid catalyzed dissociation were also evaluated and compared to other systems. The ligands involved in this work are presented in the Chart 1.

\section{Experimental Section}

\section{General}

The ligand PCTA was prepared as previously described. ${ }^{16}$

\section{Thermodynamic Stability Constants}

Stock solutions of the $\mathrm{MgCl}_{2}, \mathrm{CaCl}_{2}, \mathrm{ZnCl}_{2}, \mathrm{CuCl}_{2}, \mathrm{YCl}_{3}$ and $\mathrm{LnCl}_{3}$ were prepared from analytical grade salts (Aldrich and Sigma, 99.9\%). The concentration of the stock solutions were determined by complexometric titration using standardized $\mathrm{Na}_{2} \mathrm{H}_{2}$ EDTA solution in the presence of Eriochromeblack T $\left(\mathrm{MgCl}_{2}\right.$, and $\left.\mathrm{ZnCl}_{2}\right)$, Calconcarboxylic acid $\left(\mathrm{CaCl}_{2}\right)$, Murexide $\left(\mathrm{CuCl}_{2}\right)$ or Xylenol orange $\left(\mathrm{YCl}_{3}\right.$ and $\left.\mathrm{LnCl}_{3}\right)$ as an indicator. ${ }^{26} \mathrm{~A}$ stock solution of the ligand was prepared and the ligand concentration was determined by $\mathrm{pH}$-potentiometry on the basis of the titration curves obtained in the absence and presence of excess $\mathrm{CaCl}_{2}$. The protonation constants of the ligand were calculated from the data obtained by titrating $2 \mathrm{mM}$ and $5 \mathrm{mM}$ samples (374 data points) with standardized $\mathrm{KOH}$ solution $(0.2 \mathrm{M})$ in the absence of $\mathrm{Ca}^{2+}$ in the $\mathrm{pH}$ range of 1.7-12.2. The protonation constants of the ligand $\left(\log K_{i}^{H}\right)$ are defined as follows:

$$
\mathrm{K}_{i}^{H}=\frac{\left[H_{i} L\right]}{\left[H_{i-1} L\right]\left[H^{+}\right]}
$$

where $\mathrm{i}=1,2, \ldots, 5$ and $\left[\mathrm{H}_{\mathrm{i}-1} \mathrm{~L}\right]$ and $\left[\mathrm{H}^{+}\right]$are the equilibrium concentrations of the ligand $(\mathrm{i}=1)$, protonated forms of the ligand $(\mathrm{i}=2, \ldots, 5)$ and hydrogen ions, respectively. The hydrogen ion concentrations were calculated from the measured $\mathrm{pH}$ values as described in the literature. ${ }^{27}$ Briefly, a $0.01 \mathrm{M} \mathrm{HCl}$ solution (in $1.0 \mathrm{M} \mathrm{KCl}$ ) was titrated with standardized $\mathrm{KOH}$ solution and the differences between the measured and calculated $\mathrm{pH}$ values were used to correct the measured $\mathrm{pH}$ values. ${ }^{27}$ The ion-product of water was also established in these experiments $\left(\mathrm{pK}_{\mathrm{w}}=13.845\right)$ and used for calculations. The ionic strength of all titrated solutions was maintained constant using 1.0 M KCl (Mallinckrodt). All equilibrium measurements (direct titrations) were carried out in $10.00 \mathrm{~mL}$ sample volumes with magnetic stirring under argon atmosphere at $25^{\circ} \mathrm{C}$ using a $665 \mathrm{Metrohm}$ Dosimat autoburet. The $\mathrm{pH}$ was measured with a Ross semi-micro combination electrode (Orion) combined with a Thermo Orion IonAnalyzer EA 940. The electrode was calibrated by $\mathrm{KH}$-phthalate $(\mathrm{pH}=4.005)$ and Na-tetraborate $(\mathrm{pH}=9.180)$ (Alfa Aesar). The titrant $(\mathrm{KOH})$ was prepared using degassed twice distilled water and its concentration was standardized by titration with $\mathrm{KH}$-phthalate. The solution was kept under argon atmosphere to prevent entry of $\mathrm{CO}_{2}$.

The potentiometric measurements for systems that reach equilibrium rapidly $\left(\mathrm{M}^{2+}\right.$ metal ions) were carried out by use of a computer controlled automated titration system. Stability constants for doubly charged metal ions were determined from titration data preformed at 2:1, 1:1 and 1:2 metal-to-ligand ratios, and the number of points fitted varied between 176 - 321 data pairs. Owing to the slow formation reactions of Y(PCTA) and Ln(PCTA) complexes, an "out-ofcell" technique was applied for the stability determinations. Sixteen $1.5 \mathrm{~mL}$ samples containing a known amount of ligand (with known $\mathrm{H}^{+}$concentration) and $\mathrm{Y}^{3+}$ or $\mathrm{Ln}^{3+}$ were prepared and the $\mathrm{pH}$ was adjusted to a range where complexation could be expected to take place based upon 
literature stability data for various $\mathrm{Gd}^{3+}$ and $\mathrm{Eu}^{3+}$ complexes. ${ }^{16,19,25}$ The samples were sealed under a blanket of argon and kept in an incubator at $45^{\circ} \mathrm{C}$ for one week (this time period was established by preliminary spectrophotometric studies on separate most acidic and most basic samples kept together with the rest of the "out-of-cell" samples). After this time period, the samples were removed from the incubator and re-equilibrated at room temperature (for 6-7 days). The samples were then opened and the equilibrium $\mathrm{pH}$ was measured. The stability of the hydroxo complexes was determined in a separate titration after the complexes were fully formed. In these experiments complex solutions with 1:1 metal-to-ligand ratio were prepared at around $\mathrm{pH}=6$. At this $\mathrm{pH}$ the full complexation takes only few seconds. After $\mathrm{pH}$-stabilization a titration was performed with standardized $\mathrm{KOH}$. The equilibrium of the hydroxo complex formation was rapid and the points were recorded with 1 minute intervals. A total of 84-120 data points were recorded in the $\mathrm{pH}$ range of about 6 to 12.0. The software PSEQUAD was used to process the titration data (calculation of the protonation and stability constants). ${ }^{28}$ The reliability of the protonation and stability constants are characterized by the calculated standard deviation values shown in parenthesis and fitting parameter values $(\Delta \mathrm{V}$, which is the difference between the experimental and the calculated titration curves expressed in $\mathrm{mL}$ of the titrant).

\section{Formation kinetics}

The formation rates of $\mathrm{Ce}(\mathrm{PCTA}), \mathrm{Eu}(\mathrm{PCTA}), \mathrm{Y}(\mathrm{PCTA})$ and $\mathrm{Lu}(\mathrm{PCTA})$ were studied at $25^{\circ}$ $\mathrm{C}$ and $1.0 \mathrm{M} \mathrm{KCl}$ ionic strength by direct spectrophotometry on a Cary 300Bio UV-Vis spectrophotometer using thermostated cell holders and semi-micro quartz cells (Starna, optical path length $1 \mathrm{~cm}$ ). Typically, the concentration of the ligand was $0.2 \mathrm{mM}$ while the concentration of the metal ion was varied between $0.6-4 \mathrm{mM}$ (the reaction is first order even at comparable ligand and metal ion concentrations).

Over the $\mathrm{pH}$ range $3.5-4.4$, complex formation is slow enough to follow by conventional spectrophotometry by following changes in the $\pi \rightarrow \pi^{*}$ absorption band of the ligand at $\lambda_{\max }=261 \mathrm{~nm}\left(\varepsilon_{\max }=3.85 \times 10^{3} \mathrm{dm}^{3} \mathrm{~mol}^{-1} \mathrm{~cm}^{-1}\right.$ at $\left.\mathrm{pH}=4.07\right)$. Upon coordination, this band undergoes a red shift $\left(\lambda_{\max }=269 \mathrm{~nm}\right.$ with $\varepsilon_{\max }=4.91 \times 10^{3} \mathrm{dm}^{3} \mathrm{~mol}^{-1} \mathrm{~cm}^{-1}$ for $\mathrm{Ce}^{3+}$ complex at $\mathrm{pH}=4.07$ ) as a result of metal ion coordination and the kinetics of complex formation was followed by measuring changes in absorbance at $278 \mathrm{~nm}$ (where the absorbance of the metal ions is weak $\left(\mathrm{Ce}^{3+}\right.$ and $\left.\mathrm{Eu}^{3+}\right)$ or zero $\left(\mathrm{Y}^{3+}\right.$ and $\left.\mathrm{Yb}^{3+}\right)$. Formation of $\mathrm{Ce}(\mathrm{PCTA})$ could be studied in the UV range $275-320 \mathrm{~nm}$, where the absorbance of the ligand and metal ion are negligible (Fig. 1, peaks p2 and p3) The peak at $\lambda_{\max }=269 \mathrm{~nm}$ is due to the absorbance of the pyridine unit in the complex while complexed $\mathrm{Ce}^{3+}$ has a $\lambda_{\max }=304 \mathrm{~nm}$ (Fig. 1, p3). Since the molar absorption coefficient $\left(\varepsilon_{\max }\right)$ for the $\pi \rightarrow \pi^{*}$ transitions are much higher than that for $4 \mathrm{f}-5 \mathrm{~d}$ transitions, complex formation was typically followed by changes in absorbance at $278 \mathrm{~nm}$. An experiment in which the reaction was monitored at the absorption maximum $\left(\lambda_{\max }=304\right.$ $\mathrm{nm})$ in more concentrated solution $\left(\mathrm{C}_{\mathrm{PCTA}}=1.0 \mathrm{mM}\right)$ gave an identical formation rate as measurements at $\lambda_{\max }=278 \mathrm{~nm}$. All formation kinetic studies were carried out in the noncoordinating buffer, $\mathrm{N}, \mathrm{N}^{\prime}$-dimethylpiperazine (DMP, $0.05 \mathrm{M}$ ) to maintain constant $\mathrm{pH}$. The $\mathrm{pH}$ of each sample was re-measured after full complex formation (usually on the next day) and any samples with $\mathrm{pH}$ changes greater than $0.025 \mathrm{pH}$ units were excluded from the calculations.

Equation 2 was used to calculate the first order rate constants $\left(k_{o b s}\right.$ for formation and $k_{d}$ for dissociation), where $A_{0}, A_{e}$ and $A_{t}$ are the absorbance values measured at the start of the reaction $(t=0)$, at equilibrium and at time $t$, respectively. The kinetics curves had been acquired usually until the equilibrium was reached and to obtain the rate constants the complete kinetics curves were fitted. However, the dissociaton reactions in $\mathrm{C} \leq 0.5 \mathrm{M}$ of $\mathrm{HClO}_{4}$ were followed only until $85-90 \%$ conversion. The data were fitted to Equation 2 with the software Scientist ${ }^{\circledR}$ (Micromath) using a standard least square procedure. 


$$
A_{t}=A_{e}+\left(A_{0}-A_{e}\right) \cdot e^{\left(-k_{\mathrm{obs}} \cdot t\right)}
$$

The relative error for the fitting of the absorbance $v s$. time curves in all cases was lower than $1 \%$ and the calculated first order rate constants $k_{o b s}$ and $k_{p}$ values were reproduced within a $5 \%$ error as determined in 5 identical experiments.

\section{Kinetics of Dissociation}

Acid catalyzed dissociation kinetics of Ce(PCTA), Eu(PCTA), Y(PCTA) and Lu(PCTA) were studied in $0.05-3.12 \mathrm{M} \mathrm{HClO}_{4}\left(\mathrm{NaClO}_{4}\right.$ was added to maintain the ionic strength of $3.12 \mathrm{M}$ $\left.\left(\mathrm{H}^{+}+\mathrm{Na}^{+}\right) \mathrm{ClO}_{4}^{-}\right)$and usually $17-24$ data points were obtained at $25^{\circ} \mathrm{C}$. The $\mathrm{HClO}_{4}$ stock solution (approximately $4.0 \mathrm{M}$ ) was standardized by acid-base titration against a standard $\mathrm{NaOH}$ solution in the presence of phenolphthalein as an indicator. The $\mathrm{NaClO}_{4}$ solution was prepared by weighing out an appropriate quantity of $\mathrm{NaClO}_{4}$. The reactions were followed in $0.25 \mathrm{mM}$ complex solutions by direct spectrophotometry at $278 \mathrm{~nm}$, and the complex concentrations were adjusted so that changes of $\sim 0.6$ abs. units were detected throughout the dissociation reaction.

\section{Results and Discussion}

\section{Protonation and stability constant determinations}

The ligand, PCTA, has seven protonation sites but only four protonation constants have been detected by using either ${ }^{1} \mathrm{H}$ NMR spectroscopy or pH-potentiometry. ${ }^{16,23-25}$ Delgado and coworkers originally ascribed the first protonation step to occur at the pyridine nitrogen ${ }^{23}$ yet Aime et al. later showed by ${ }^{1} \mathrm{H}$ NMR that the most basic site of the ligand is the nitrogen atom opposite to the pyridine ring. ${ }^{16}$ Addition of a second proton results in a rearrangement of ring protons such that the two protons shift to the two tertiary nitrogen atoms positioned trans- to each other in the macrocyclic ring and cis to the pyridine nitrogen. In earlier studies, the protonation constants were determined using relatively low ligand concentrations (1.67 and 1 $\mathrm{mM}$ respectively) in $0.1 \mathrm{M} \mathrm{Me}_{4} \mathrm{NNO}_{3}$ or $\mathrm{KCl}$. $^{23-25}$ At such low concentrations, only a small portion of the added base is neutralized by the ligand protons in the $\mathrm{pH}$ range 11-12 and this results in a significant degree of uncertainty in evaluation of the protonation constants in this range. ${ }^{29}$ Here, we determined the protonation constants from titration data generated using two high ligand concentrations ( 2 and 5 times higher than reported earlier $23-25$ ) and both titration curves were fitted simultaneously. The ion product of water as determined by allowing this parameter to vary in the fitting procedure $\left(\mathrm{pK}_{\mathrm{W}}=13.85 \pm 0.01\right)$ and as determined by a separate titration $\left(\mathrm{pK}_{\mathrm{W}}=13.845\right)$ in the $\mathrm{pH}$ range 10.92-12.21 was in close agreement. A fifth protonation constant was also included in fitting procedure since the titration was initiated at a starting $\mathrm{pH}$ of 1.7. Since the stability constants of the $\mathrm{Ln}$ (PCTA) and Y(PCTA) complexes were determined in acidic samples (the final equilibrium $\mathrm{pH}$ of the samples was in the $\mathrm{pH}$ range from 1.75-to 2.50), the value of $\log K_{5}{ }^{H}$ will impact this calculation. The protonation constants determined in this work are compared with previously reported literature values for PCTA and other related ligands in Table 1.

The stability constants of $\mathrm{Mg}^{2+}, \mathrm{Ca}^{2+}, \mathrm{Zn}^{2+}$ and $\mathrm{Cu}^{2+}$ ions with $\mathrm{PCTA}^{3-}$ were reported previously by Delgado, et al. ${ }^{23}$ However, as there was a significant difference between the total ligand basicity of the ligand determined here in comparison to the values reported by Delgado, the stabilities of these same complexes were redetermined in $1.0 \mathrm{M} \mathrm{KCl}$. The stability constants of PCTA, NOTA, DO3A and DOTA with $\mathrm{Mg}^{2+}, \mathrm{Ca}^{2+}, \mathrm{Zn}^{2+}$ and $\mathrm{Cu}^{2+}$ are summarized in Table 2. The values obtained in this study are somewhat higher than the values reported earlier largely due to differences in ligand basicity $\left(\Sigma \log K_{i}{ }^{H}\right)$ between the two studies. As noted by Delgado et al. the stability of $\mathrm{Zn}$ (PCTA)- is somewhat higher than that of $\mathrm{Cu}$ (PCTA)- (opposite that predicted by the Irving-Williams order). In the absence of X-ray 
structures, it is difficult to explain the origin of these differences but the higher stability of $\mathrm{Zn}$ (PCTA $)^{-}$compared to $\mathrm{Cu}(\mathrm{PCTA})^{-}$suggests that PCTA could potentially be used for the selective complexation of $\mathrm{Zn}^{2+}$ over the $\mathrm{Cu}^{2+}$.

Fewer thermodynamic studies of the Ln(PCTA) complexes have appeared likely due to slow complexation kinetics that excludes the use of conventional $\mathrm{pH}$-potentiometry. The stability constant for $\mathrm{Gd}(\mathrm{PCTA})$ was however determined by Aime et al. by competitive binding between DTPA and PCTA for the $\mathrm{Gd}^{3+}$. The competition reaction was followed by relaxometry and the stability constant was reported as $\log K_{G d L}=21.0 .{ }^{16}$ More recently, Siaugue and coworkers studied the luminescence properties of $\mathrm{Eu}^{3+}$ with azapyridinomacrocycles and reported stability constants for $\mathrm{Eu}(\mathrm{PCTA})$ also in the range, $\log K_{E u L}=21 .{ }^{19}, 25$ Due to slow complex formation, we determined the stability constants of PCTA with $\mathrm{Ce}^{3+}, \mathrm{Nd}^{3+}, \mathrm{Eu}^{3+}$, $\mathrm{Y}^{3+}, \mathrm{Ho}^{3+}$ and $\mathrm{Yb}^{3+}$ ions using an "out-of-cell" potentiometric method. Only mononuclear species (ML) were found for the $\mathrm{Ln}\left(\mathrm{PCTA}\right.$ ) complexes and for $\mathrm{Ce}^{3+}, \mathrm{Nd}^{3+}$ and $\mathrm{Y}^{3+}$ the stability constants of the protonated MHL complexes could also be calculated from the "out-of-cell" data. The stability of the hydroxo complexes was determined in a separate titration after the complexes were fully formed. The stability constants for $\mathrm{Ln}(\mathrm{PCTA})$ and Y(PCTA) are listed in Table 3. These data differ somewhat from the published values (they are smaller than the reported literature values by about $0.6-0.8 \log K$ units). This difference, however, is acceptable due to the relatively greater error associated with the competitive relaxometric method used by Aime et al. ${ }^{16}$

The stability constants of the $\mathrm{Ln}(\mathrm{PCTA})$ complexes increase from $\mathrm{Ce}^{3+}$ to $\mathrm{Eu}^{3+}$ then remain relatively constant for the heavier lanthanides with a slight increase toward the end of the series $\left(\mathrm{Yb}^{3+}\right)$. This trend, similar to that found for the $\mathrm{Ln}(\mathrm{NOTA})$ and $\mathrm{Ln}(\mathrm{DOTA})^{-}$complexes, ${ }^{34}$ indicates that the size match between the lanthanide ion and the coordination cage determined by the four $\mathrm{N}$-atoms of the macrocyclic ring and the three carboxylate $\mathrm{O}$-atoms is more favorable for the heavier lanthanides (from $\mathrm{Eu}^{3+}$ through $\mathrm{Lu}^{3+}$ ). The total basicity of PCTA $\left(\Sigma \log K_{i}^{H}\right)$ is about three orders of magnitude less than that of DO3A (Table 1) and four orders of magnitude higher than NOTA. Based upon total basicity comparisons of NOTA, PCTA, and DO3A, one would predict a priori stability constants on the order of $\log \mathrm{K} \sim 17-18$ for Ln(PCTA) complexes. Interestingly, the experimentally determined values (Table 3) were two $\log K$ units higher than that predicted on the basis of basicity alone. This difference may be attributed in part to preorganization of the macrocyclic cavity by the pyridine ring.

\section{Kinetics of Complex Formation}

The complex formation rates of $\operatorname{Ln}(\mathrm{III})$ ions with macrocyclic ligands are typically several orders of magnitude slower than the rates of complex formation with flexible multidentate ligands like DTPA. PCTA has a convenient built-in chromophore due to a $\pi \rightarrow \pi^{*}$ transition of the pyridine moiety, the maximum of which exhibits a red shift upon complexation with a metal ion (Figure 1). The red shift was large enough to be used to monitor the complex formation. Owing to the high $\varepsilon_{\max }$ (for $\mathrm{Ce}\left(\right.$ PCTA) $\varepsilon_{\max }=4.91 \times 10^{3} \mathrm{dm}^{3} \mathrm{~mol}^{-1} \mathrm{~cm}^{-1}$ at $\lambda_{\max }=$ $269 \mathrm{~nm}$ and $\mathrm{pH}=4.07)$, large changes in absorbance were registered even in quite dilute solutions $(0.2 \mathrm{mM})$. The kinetics of formation were studied for four metal ions $\mathrm{Ce}^{3+}, \mathrm{Eu}^{3+}$, $\mathrm{Y}^{3+}$ and $\mathrm{Yb}^{3+}$ in the presence of $3-20$ fold excess metal ion.

In the presence of excess $\mathrm{Ln}^{3+}$, the rate of complex formation may be described as:

$$
\frac{d[\mathrm{LnL}]_{t}}{\mathrm{dt}}=k_{\mathrm{obs}}[\mathrm{PCTA}]_{0}
$$

where $[\mathrm{PCTA}]_{0}$ is the total concentration of the free ligand and $k_{o b s}$ is a pseudo first order rate constant. The formation reactions were investigated in the $\mathrm{pH}$ range $3.56-4.40$ with 7 to $9 \mathrm{pH}$ 
readings while varying the concentrations of $\mathrm{Ce}^{3+}, \mathrm{Eu}^{3+}$ or $\mathrm{Y}^{3+}$ and in the $\mathrm{pH}$ range of 3.56 4.07 with $5 \mathrm{pH}$ readings for formation of the $\mathrm{Yb}^{3+}$ complex. At higher $\mathrm{pH}$ values, complex formation was too fast to be followed by conventional spectrophotometry and below $\mathrm{pH} 3$, complex formation was not complete. A plot of pseudo-first-order rate constants versus concentration of $\mathrm{Ln}^{3+}$ and/or $\mathrm{Y}^{3+}$ showed a saturation curve at all $\mathrm{pH}$ readings (Fig. 2 for Eu (PCTA) and Y(PCTA) and Fig. S1 in electronic supporting information for $\mathrm{Ce}(\mathrm{PCTA})$ and $\mathrm{Yb}$ (PCTA) complexes). This behavior can be described by rapid formation of an intermediate protonated complex that rearranges to the final product, $\mathrm{Ln}(\mathrm{PCTA})$, in a slow rate-determining step. ${ }^{37}$ A similar mechanism has been reported for other $\operatorname{Ln}(\mathrm{III})$ macrocyclic polyaminopolycarboxylic acid ligands ( $\operatorname{Ln}\left(\right.$ NOTA), $\operatorname{Ln}(\mathrm{DO} 3 \mathrm{~A}), \mathrm{Ln}(\mathrm{DOTA})^{-}, \mathrm{Ln}(\mathrm{TRITA})^{-}, \mathrm{Ln}$ (TETA) ${ }^{-5-14}$

The dependence of $k_{o b s}$ values on the metal ion concentration may be described by Eqn. 4 :

$$
k_{\mathrm{obs}}=\frac{k_{r} K_{\mathrm{cond}}^{\mathrm{Ln}\left(\mathrm{H}_{2} \mathrm{PCTA}\right)^{2+}}\left[\mathrm{Ln}^{3+}\right]}{1+K_{\mathrm{cond}}^{\mathrm{Ln}\left(\mathrm{H}_{2} \mathrm{PCTA}\right)^{2+}}\left[\mathrm{Ln}^{3+}\right]}
$$

where $K_{\text {cond }}^{\mathrm{Ln}\left(H_{2} \mathrm{PCTA}\right)^{2+}}$ is the conditional stability constant of the intermediate and $k_{r}$ is the rate constant for deprotonation and rearrangement of the intermediate to the product. The diprotonated complex, $\mathrm{Ln}\left(\mathrm{H}_{2} \mathrm{PCTA}\right)^{2+}$, as identified as a common intermediate by $\mathrm{pH}-$ potentiometry $\left(\mathrm{Ce}^{3+}, \mathrm{Eu}^{3+}\right.$ and $\left.\mathrm{Y}^{3+}\right)$ and UV-VIS spectrophotometry $\left(\mathrm{Yb}^{3+}\right)$. When the reactants were mixed in weakly buffered solution, a rapid $\mathrm{pH}$ drop was first observed followed by the slow decrease in the $\mathrm{pH}$. The number of protons released in each of these steps could be determined in an independent titration from the amount of base needed to neutralize the same amount of buffer solution. However, the number of the protons released in the first step depended upon the starting $\mathrm{pH}$ of the buffer used. For the metal ions examined here, the composition of the intermediate was determined at $\mathrm{pH}=3.86$ in weakly buffered solutions $(0.01$ M, DMP). On mixing solutions of the ligand in the form, $\mathrm{H}_{2.5}$ PCTA and $\mathrm{Ln}^{3+}$

$\left(\mathrm{C}_{\mathrm{PCTA}}=5 \times 10^{-4} \mathrm{M}, \mathrm{C}_{\mathrm{Ln} 3+}=2.5 \times 10^{-3}, \mathrm{~V}=10.00 \mathrm{~mL}\right)$ the amount of protons released in the slow process was about four times more than in the initial step. This suggests that the intermediate is the diprotonated complex, $\mathrm{Ln}\left(\mathrm{H}_{2} \mathrm{PCTA}\right)^{2+}$. Due to rapid formation of the $\mathrm{Yb}(\mathrm{PCTA})$ complex, $\mathrm{pH}$ changes upon complexation cannot be followed with an electrode. Therefore, a spectrophotometic method was used to ensure that the intermediate in this system is the diprotonated, $\mathrm{Yb}\left(\mathrm{H}_{2} \mathrm{PCTA}\right)^{2+}$, complex. The conditions for this experiment were similar that listed above, but the $\mathrm{pH}$ changes upon the mixing of the reactants was followed spectrophotometrically with the use of an acid base indicator (Methyl Orange, $\mathrm{pH}$ range 3.1-4.4, $\mathrm{C}_{\mathrm{MO}}=2 \times 10^{-5} \mathrm{M}, \mathrm{V}=1.20 \mathrm{~mL}$ ). The absorbance changes of the sample containing indicator in weakly buffered solutions ( $0.01 \mathrm{M}, \mathrm{DMP})$ were calibrated by addition of known amount of acid $(0.1084 \mathrm{M} \mathrm{HCl} 5 \mu \mathrm{L})$. A kinetic curve was then recorded for the system, $\mathrm{H}_{2.5}$ PCTA plus 5 equivalents of $\mathrm{Yb}^{3+}$. The changes in the absorbance can be expressed in the volume of added acid $(0.1084 \mathrm{M} \mathrm{HCl})$ and the approximate amount of protons released can thus be determined. Similarly to other $\operatorname{Ln}(\mathrm{III})$ ions studied, the experiments strongly suggest the formation of a diprotonated intermediate, $\mathrm{Yb}\left(\mathrm{H}_{2} \mathrm{PCTA}\right)$. Diprotonated intermediates have been identified in the complexation reactions of $\mathrm{Ln}(\mathrm{DOTA})^{-}$, various LnDOTA derivatives, Ln(TRITA) ${ }^{-}$and Ln(TETA) ${ }^{-}$complexes. ${ }^{7-9,12-14,38}$ However, for $\operatorname{Ln}($ NOTA) and for complexes of some DO3A derivatives, monoprotonated intermediates has been found. 5 , $10-11$ It was found that the protonation degree of the intermediate depended on the relative values of protonation constants of the nitrogen atoms and on the differences between them. The first two protonation constants of some 9 and 10 membered macrocyclic ligands such as NOTA, DETA were found to differ with 6-8 orders of magnitude, which is possibly the reason for the presence of monoprotonated $(\operatorname{Ln}(\mathrm{HL}))$ intermediates. ${ }^{5-6}$ In the case of PCTA, the 
difference between the first and second protonation constants were found to be $\left(\log K_{1}{ }^{H_{-}} \log \right.$ $\mathrm{K}_{2}{ }^{\mathrm{H}}$ ) $3.99 \log \mathrm{K}$ units, which lies between the value obtained for DOTA and NOTA (2.33-2.90 and 4.74-6.31, respectively, Table 1).

The final form of the equations used for fittings is Eqn. 5 (for additional equations see electronic supporting information):

$$
k_{\mathrm{obs}}=\frac{k_{r} \frac{K_{\text {therm }}^{\mathrm{Ln}\left(H_{2} \mathrm{PCTA}\right)^{2+}}}{\alpha_{H_{2} L}}\left[\mathrm{Ln}^{3+}\right]}{1+\frac{K_{\text {therm }}^{\mathrm{Ln}\left(H_{2} \mathrm{PCTA}\right)^{2+-}}}{\alpha_{{ }_{H_{2}} \mathrm{PCTA}}}\left[\mathrm{Ln}^{3+}\right]}
$$

The $k_{o b s}$ values at different $\mathrm{pH}$ and $\mathrm{Ln}^{3+}$ ion concentrations were fitted to eq. 6 and the rate constants $k_{r}$ and the stability constants of the intermediates $\left(K_{\text {therm }}^{\mathrm{Ln}\left(H_{2} \mathrm{PCTA}\right)^{2+}}\right)$ were calculated for each of the metal ions studied. Because of the relative fast formation of the complexes, it was impossible to obtain stability constants of the intermediates by $\mathrm{pH}$-potentiometric titration (no reliable data can be obtained). From kinetic data, the stability constants of the intermediate species were found to be reasonably $\mathrm{pH}$ independent over the $\mathrm{pH}$ range examined (calculated stability constants at each $\mathrm{pH}$ readings are listed in electronic supporting information Table $\mathrm{S} 1)$. The average of the stability constants of the intermediates, $\mathrm{Ce}\left(\mathrm{H}_{2} \mathrm{PCTA}\right)^{2+}, \mathrm{Eu}$ $\left(\mathrm{H}_{2} \mathrm{PCTA}\right)^{2+}, \mathrm{Y}\left(\mathrm{H}_{2} \mathrm{PCTA}\right)^{2+}$ and $\mathrm{Y}\left(\mathrm{H}_{2} \mathrm{PCTA}\right)^{2+}$, were $2.81 \pm 0.03,3.12 \pm 0.02,2.97 \pm 0.06$ and $2.69 \pm 0.06$, respectively. The values obtained from the kinetic data are higher than those for the monoacetate complexes $\left(\mathrm{Ln}\left(\mathrm{CH}_{3}-\mathrm{COO}\right)^{2+}\right)$. On the other hand the stability of $\mathrm{La}^{3+}$ and $\mathrm{Y}^{3+}$ complexes formed with dicarboxylic acid-glutarate are 3.02 and 3.25, respectively, which are close to the values obtained in our study indicating that the number of acetate arms coordinated to metal ion in the intermediates was likely greater than one and most likely two. 38 The stability constants calculated from the kinetic data of the intermediates are lower than those obtained from $\mathrm{pH}$-potentiometric titration for the $\mathrm{Ln}\left(\mathrm{H}_{2} \mathrm{DOTA}\right)^{+}$complexes $(4.4,4.3$, and 4.2 for $\mathrm{Ce}, \mathrm{Eu}$ and $\mathrm{Yb}$ intermediates, respectively) and somewhat higher than those reported for a DO3A derivative ligand $(2.4,2.5$, and 2.43 for the $\mathrm{Ce}, \mathrm{Eu}$ and $\mathrm{Yb}$ intermediates, respecively). 8,39

The rate constants $k_{r}$ are inversely proportional to the $\mathrm{H}^{+}$ion concentration as $k_{O H}=k_{H} / \mathrm{K}_{\mathrm{w}}$ $\left(\left[\mathrm{H}^{+}\right]\left[\mathrm{OH}^{-}\right]=\mathrm{K}_{\mathrm{w}}\right.$; where $\mathrm{K}_{\mathrm{w}}$ is the ionic product of water). (eqn. 6 and Fig. 3 ).

$$
k_{r}=\frac{k_{H}}{\left[H^{+}\right]}=k_{\mathrm{OH}}\left[\mathrm{OH}^{-}\right]
$$

Similar relations were found for a large number of 9- to 14-membered tri- or tetraazamacrocyles with three or four carboxylate-containing side arms. ${ }^{5-14}$ Interestingly, among all acetate derivatives studied, $\mathrm{Ce}$ (TETA) ${ }^{-}$is an exception in that this complex shows a second order dependence. ${ }^{40}$ This behavior was explained by a hydroxide ion catalyzed rearrangement of the ligand TETA, a ligand that is less pre-organized than DOTA. The $k_{O H}$ values are presented and compared to different tri- and teraazamacrocyle ligands in Table 4.

The tetraaza macrocycle PCTA can be regarded as a more pre-organized triacetate derivative of DOTA or DO3A. Due to the similarities in their structures, the complex formation mechanism is expected to be similar to that of DOTA. ${ }^{8-9}$ The linear dependence of the complex formation on the $\mathrm{OH}^{-}$ion concentration can be interpreted as rapid deprotonation of the intermediate $\mathrm{Ln}\left(\mathrm{H}_{2} \mathrm{PCTA}\right)^{2+}$ to $\mathrm{Ln}(\mathrm{HPCTA})^{+}$in an equilibrium step followed by release of the second proton in a rate-determining step. It is easy to prove that concentration of the monoprotonated complex is inversely proportional to the $\mathrm{H}^{+}$ion (or linearly proportional to 
the $\mathrm{OH}^{-}$ion) concentration. The validity of general base catalysis has been shown for DOTA and some DO3A derivatives 9,39 and also in our case, the $k_{o b s}$ values depend linearly on the buffer concentration (basic form of the buffer, not shown). The evidence for the existence of general base catalysis supports the rate controlling role of the deprotonation of the monoprotonated intermediate and formation of the $\mathrm{Ln}$ (PCTA) complexes. Deprotonation is followed by a fast structural rearrangement in which the metal ion moves to the "coordination cage" defined by the ligand. The proposed reaction steps for the formation of $\operatorname{Ln}(\mathrm{PCTA})$ complexes is illustrated in Scheme 1. However, it is worth mentioning that the plot of $k_{r}$ vs. $\left[\mathrm{OH}^{-}\right]$for all studied metal ions can also be fitted with second order dependence on $\mathrm{OH}^{-}$ion concentration, as it was found for the formation of Ce(TETA)-. ${ }^{40}$ In these cases the $k_{O H}$ rate constants deviate from the values presented in Table 4 by $\sim 25 \%$, but the errors in the $k_{O H}$ and $k_{2 O H}$ values cannot be determined by the program, possibly because of the limited interval of $\mathrm{pH}$ used for the study.

The data of Table 4 indicates that the formation rates of the $\operatorname{Ln}(\mathrm{PCTA})$ complexes are at least 1 order of magnitude faster than they are for the corresponding Ln(DOTA)- complexes. Because of the presence of a pyridine moiety, PCTA seems to be more pre-organized than other tetraaza macrocycles. Kumar et al. found a linear correlation between the rate of rearrangement of the intermediate and the first protonation constant of the ligand. ${ }^{10} \mathrm{~A}$ similar correlation can be established for GdL complexes of several 12-membered tri- and tetraacetate (DOTA and DO3A-derivatives) ligands based on literature data (Fig. 4., the values used for generation of the figure are listed in ESI Table S3). It is important to note, however, that the $\log K_{l}{ }^{H}$ values of the ligands strongly depend on the ionic strength used in each experiment. The rate of formation of $\mathrm{Eu}$ (PCTA) (red square) as determined in this work is somewhat higher than expected based on $\log K_{l}^{H}$ value, which can be attributed in a part to the more preorganized structure of PCTA (the rates of formation for two neighboring $\mathrm{Ln}$ (III) ions differ only slightly and $\mathrm{Eu}(\mathrm{PCTA})$ can be compared to the Gd(PCTA). The X-ray structure of the parent macrocyclic amine, pyclen, indicates a preorganized, rigid structure ${ }^{20}$ but in the absence of X-ray crystallographic data for PCTA ligand itself or of some $\operatorname{Ln}($ PCTA) complexes, it is difficult to ascribe the unusually fast formation kinetics exclusively to pre-organization.

\section{Kinetics of Dissociation}

The kinetics of complex dissociation is an important parameter to consider if the Ln(PCTA) complexes are to be used in vivo. In the past two decades the dissociation kinetics of several $\mathrm{Ln}^{3+}$-polyaminopolycarboxylate complexes formed with both open chain and macrocyclic ligands have been studied by various methods. ${ }^{3}$ Based on these data, the dissociation of the complexes in vivo can occur through one of the following pathways (Scheme 2): 1) spontaneous dissociation characterized by the rate constant $\left.k_{L n L}, 2\right)$ proton assisted dissociation characterized with the protonation constants $\mathrm{K}^{\mathrm{H}} \mathrm{LnHL}$ and $\mathrm{K}^{\mathrm{H}}{ }_{\mathrm{LnH} 2 \mathrm{~L}}$ and rate constants $k_{L n H L}$ and $\left.k^{H}{ }_{L n H L}, 3\right)$ ligand assisted dissociation characterized by the stability constant of mixed ligand complexes $\mathrm{K}_{\mathrm{LLnL}}$ and rate constant $k_{L L n L^{*}}$, and 4) metal-ion catalyzed dissociation characterized by the stability of dinuclear complexes $\mathrm{K}_{\mathrm{LnLM}}$ and rate constant $k_{L n L M}$. The rate of the dissociation is directly proportional to the total concentration of the complex:

$$
-\frac{d[\mathrm{LnL}]_{t}}{\mathrm{dt}}=k_{d}[\mathrm{LnL}]_{t}
$$

where the $k_{d}$ is a pseudo-first-order rate constant. Taking into account of all possible dissociation pathways according to Scheme 2 the total concentration of the complex $[\mathrm{LnL}]_{\mathrm{t}}$ can be expressed as:

$$
[\mathrm{LnL}]_{t}=[\mathrm{LnL}]+[\mathrm{LnHL}]+\left[\mathrm{LnH}_{2} L\right]+[\mathrm{LnLM}]+\left[\mathrm{LLnL}^{*}\right]
$$


In the systems $\operatorname{Ln}(\mathrm{III})$ ion and octa- or nonadentate macrocyclic ligands the probability of a ligand exchange reaction is very low as formation of ternary complex $\left(\mathrm{LLnL}^{*}\right)$ is unlikely. The stabilities of the complexes of $\mathrm{Ln}^{3+}$ ions formed with endogenous ligands (e.g. citrate, glutamate) are several orders of magnitude less than they are for macrocyclic $\mathrm{Ln}^{3+}$ polyaminopolycarboxylate complexes. ${ }^{38}$ On the other hand the metal ion catalyzed dissociation have not been detected neither for $\operatorname{Ln}(\mathrm{NOTA})$ and $\mathrm{Ln}(\mathrm{DO} 3 \mathrm{~A})$ nor for $\mathrm{Ln}$ (DOTA)-, possibly due to the absence dinuclear LnLM complexes. However, this is an important dissociation route for $\mathrm{Ln}^{3+}$ complexes formed with DTPA-derivatives and macrocyclic ligands derived from larger cyclic amines such as Ln(TRITA) ${ }^{-}$and Ln(TETA)3,13 In general, for 12-membered tetraazamacrocyles with three to four acetate pendant arms including PCTA, eqn. 8 can be simplified to:

$$
[\mathrm{LnL}]_{t}=[\mathrm{LnL}]+[\mathrm{LnHL}]+\left[\mathrm{LnH}_{2} L\right]
$$

The acid catalyzed dissociation rates of $\mathrm{Ln}(\mathrm{PCTA})\left(\mathrm{Ce}^{3+}, \mathrm{Eu}^{3+}\right.$ and $\left.\mathrm{Yb}^{3+}\right)$ and $\mathrm{Y}(\mathrm{PCTA})$ were studied in weak acid $\left(0.05-3.12 \mathrm{M} \mathrm{HClO}_{4}\right)$ where the complexes are thermodynamically unstable and dissociate completely. The rates of dissociation can be expressed by eqn. 7 and the plot of the obtained $k_{d}$ values vs. $\mathrm{H}^{+}$concentration is shown in Fig. 5 .

In general two types of curves were observed: 1) the rate of dissociation is linearly proportional to acid concentration (Eu(PCTA) and $\mathrm{Yb}(\mathrm{PCTA})$ in the concentration range $0.05-1.0 \mathrm{~mol} /$ $\mathrm{dm}^{3}$ ) and 2) saturation kinetics (Ce(PCTA), Y(PCTA) and $\mathrm{Yb}(\mathrm{PCTA})$ at high acid concentrations). Similar results were reported for rates of dissociation of complexes formed with other macrocyclic ligands. $5-8,11,13-14,35,41$ The saturation kinetics are in good agreement with presence of an intermediate protonated complex rapidly forming at the beginning of the reaction. The protonation likely occurs first on the acetate oxygen atom(s), and then the proton is transferred to the nitrogen atom(s) of the ring. After the proton transfer the metal ion moves out of the macrocyclic ring cavity ("coordination cage") and the dissociation takes place from this species where the metal ion is in "out-of-cage" position. In slightly different scenarios, either the proton transfer or the structural rearrangement or both may occur slowly. During the rearrangements a second protonation may occur on ring nitrogen atom and as a result of the electrostatic repulsion the $\mathrm{Ln}^{3+}$ leaves the "coordination cage".

For the linear correlation, the dissociation rate $\left(k_{d}\right)$ can be expressed as follows:

$$
k_{d}=k_{0}+k_{1} \cdot\left[H^{+}\right]
$$

where $k_{0}$ is a constant that describes dissociation independent on the acid concentration (most likely the spontaneous dissociation) and $k_{l}$ a constant describing acid catalyzed dissociation. Small, and in some cases even negative, values with large errors were obtained for $k_{0}$ during the fitting procedures (see ESI for details). This is not surprising as the spontaneous dissociation pathway is negligible in strongly acidic solutions, where the formation of a protonated species predominates. Therefore, during the fittings the $k_{0}$ values have been set to 0 . The rate of the spontaneous dissociation of the $\operatorname{Ln}(\text { DOTA })^{-}$complexes was also reported to be extremely low, and can be measured directly with high errors. However, comparing the spontaneous dissociation rate of $\mathrm{LnL}$ complexes formed with 9- to 14-membered macrocyclic ligands with the acid catalyzed dissociation rate of these complexes, the rate of spontaneous dissociation can be predicted (at about 4-6 order of magnitude lower than the acid catalyzed dissociation). According to our assumption the order of magnitude of the spontaneous dissociation of $\mathrm{Ln}$ (PCTA) complexes can be predicted and values of $10^{-8}-10^{-9} \mathrm{~s}^{-1}$ would be expected. The values are negligibly small, but it is worth noting that at physiological conditions, spontaneous dissociation may have larger contribution to the dissociation rate (eqn. 10) than the term $k_{l}$. $\left[\mathrm{H}^{+}\right]$, due to the low acid concentration at $\mathrm{pH}=7.4$. 
The linear dependence of $k_{p}$ on $\mathrm{H}^{+}$ion concentration in the entire range was detected for $\mathrm{Eu}$ (PCTA) and it is in a good agreement with the dissociation of the mono protonated Eu (HPCTA) ${ }^{+}$complexes. For dissociation of $\mathrm{Ce}(\mathrm{PCTA}) \mathrm{Y}(\mathrm{PCTA})$ and $\mathrm{Yb}(\mathrm{PCTA})$, saturation curves were obtained. It can be interpreted by assuming the accumulation of diprotonated complexes with the increase of $\mathrm{H}^{+}$ion concentration. For these complexes, dissociation will proceed with the formation of mono- and diprotonated $\left(\mathrm{Ln}(\mathrm{HPCTA})^{+}\right.$and $\left.\mathrm{Ln}\left(\mathrm{H}_{2} \mathrm{PCTA}\right)^{2+}\right)$ species. In these complexes, presumably the acetate group(s) are protonated in equilibrium processes. The proton transfer to the ring nitrogen atom(s) in the mono protonated species can be the rate determining step, especially at lower $\mathrm{H}^{+}$ion concentrations, where the concentration of the protonated species are low. At higher proton concentration the diprotonated species are predominant and they rearrange in the rate determining step to an intermediate in which the metal ion is coordinated only by 3 acetate arms in "out-of-cage" position. The dissociation of this intermediate will therefore be very fast. This dissociation mechanism is analogous to the one suggested by Tóth et al. for dissociation of $\mathrm{Eu}(\mathrm{DOTA})^{-}$and by other authors for dissociation of some DO3A derivatives (e.g. Kumar et al. for Gd(DO3A) and Gd(HP-DO3A) and Kang et al. for Gd(DO3MA)). ${ }^{8,41}$ Taking into account all possible dissociation pathways the rate of dissociation can be given as:

$-\frac{d[\operatorname{Ln}(\mathrm{PCTA})]_{t}}{\mathrm{dt}}=k_{d}[\operatorname{Ln}(\mathrm{PCTA})]_{t}=k_{0}[\operatorname{Ln}(\mathrm{PCTA})]+k_{1}\left[\operatorname{Ln}(\mathrm{HPCTA})^{+}\right]+k_{2}\left[\operatorname{Ln}\left(H_{2} \mathrm{PCTA}\right)^{2+}\right]$

The concentration of the protonated complexes can be calculated with the stability constants of the protonated species according to:

$$
K_{1}=\frac{\left[\operatorname{Ln}(\mathrm{HPCTA})^{+}\right]}{[\operatorname{Ln}(\mathrm{PCTA})]\left[H^{+}\right]} \text {, and } K_{2}=\frac{\left[\operatorname{Ln}\left(H_{2} \mathrm{PCTA}\right)^{2+}\right]}{\left[\operatorname{Ln}(\mathrm{HPCTA})^{+}\right]\left[H^{+}\right]}
$$

Finally, the pseudo-first-order rate constant $k_{d}$ can be expressed with Eqn. 9:

$$
k_{d}=\frac{k_{0}+k_{1} K_{1}\left[H^{+}\right]+k_{2} K_{1} K_{2}\left[H^{+}\right]^{2}}{1+K_{1}\left[H^{+}\right]+K_{1} K_{2}\left[H^{+}\right]^{2}}
$$

As described earlier, $k_{0}$ was fixed to zero and the rate constants $k_{1}$ and $k_{2}\left(k_{L n L H}\right.$ and $k^{H}{ }_{L n L H}$ from Scheme 2) and protonation constants $\mathrm{K}_{1}$ and $\mathrm{K}_{2}\left(\mathrm{~K}^{\mathrm{H}}{ }_{\mathrm{LnL}}\right.$ and $\mathrm{K}_{\mathrm{LnLH}}^{\mathrm{H}}$ from Scheme 2) were fitted to eqn. 13 .

It is possible to determine the $\mathrm{K}_{1}$ value independently by $\mathrm{pH}$-potentiometry. For the complex $\mathrm{Eu}(\mathrm{DOTA})^{-}$, Tóth and coworkers determined the protonation constant, $\mathrm{K}_{1}=14 \pm 1 .{ }^{8}$ Our attempts to determine the protonation constants of the complexes failed as no acceptable data could be obtained in titrations at about $5 \mathrm{mM}$ complex solutions with $\mathrm{HCl}$ solution. This is likely due to the fact that PCTA has lower protonation constants than DOTA and because of the lower $\log K_{i}^{H}$ values of PCTA lower $\log K_{i}^{H}$ values of the $\operatorname{Ln}($ PCTA) complexes would be expected. The $\log K_{l}{ }^{H}$ for $\mathrm{Eu}(\mathrm{DOTA})^{-}$is already quite low (1.15) ${ }^{8}$ and to determine a protonation constant lower than 1.15 would be difficult. We did not consider the use of UVVIS spectrophotometry to determine the protonated complex stability as the protonation occurs presumably on the acetate arm which is far away from the pyridine chromophore. The first order constants $\left(k_{1}\right.$ and $k_{2}$ ) obtained in the fittings of the $k_{d}$ values to eqn. 13 for $\mathrm{Ce}$ (PCTA), $\mathrm{Y}(\mathrm{PCTA})$ and $\mathrm{Yb}$ (PCTA) must be converted to the to second- and third-order rate constants for proper comparison with the literature data. The results of the fittings are listed and compared to it some other macrocyclic LnL complexes in Table 5.

The uncertainty in the products, $k_{1} \times \mathrm{K}_{1}$ and $k_{2} \times \mathrm{K}_{1} \times \mathrm{K}_{2}$, cannot be determined but the uncertainties in the first order rate constants do provide some important insights. These values 
are: $k_{l}=1.08 \pm 0.08 \times 10^{-4} \mathrm{~s}^{-1}$ and $k_{2}=1.79 \pm 0.25 \times 10^{-3} \mathrm{~s}^{-1}$ for Ce(PCTA), $k_{1}=6.24 \pm 0.58 \times 10^{-4} \mathrm{~s}^{-1}$ and $k_{2}=3.25 \pm 0.40 \times 10^{-3} \mathrm{~s}^{-1}$ for $\mathrm{Y}(\mathrm{PCTA})$ and $k_{1}=2.83 \pm 0.53 \times 10^{-4} \mathrm{~s}^{-1}$ and $k_{2}=7.98 \pm 0.24 \times 10^{-4}$ $\mathrm{s}^{-1}$ for $\mathrm{Yb}(\mathrm{PCTA})$.

Fitting the $k_{d}$ values for $\mathrm{Ce}(\mathrm{PCTA})$ and $\mathrm{Y}(\mathrm{PCTA})$ to the eqn. 13 , the rate constants $k_{1}, k_{2}$ and the protonation constants $\mathrm{K}_{1}$ and $\mathrm{K}_{2}$ could be estimated with reasonable certainty (in all cases, the uncertainty was less than 10\%). For dissociation of $\mathrm{Yb}$ (PCTA), a somewhat larger uncertainty was found when all of the data were fitted to eqn. 13. However, the correlation is linear in the $0.05-1.0 \mathrm{~mol} / \mathrm{dm}^{3} \mathrm{H}^{+}$ion concentration range and fitting the data to eqn. 10 resulted in a value $k_{1}=3.87 \pm 0.04 \times 10^{-4} \mathrm{M}^{-1} \mathrm{~s}^{-1}$ (direct dissociation of the protonated complex). This is somewhat larger than the value obtained from saturation kinetics $\left(k_{l}=2.80 \times 10^{-4} \mathrm{M}^{-1} \mathrm{~s}^{-1}\right)$. Mathematically, the rate constant $k_{1}$ calculated from the data obtained in the range 0.05-0.5 $\mathrm{M}$, at higher acid concentrations the contribution of the term $k_{1} \times \mathrm{K}_{1} \times\left[\mathrm{H}^{+}\right]$to $k_{d}$ is very low (eqn. 13) therefore the uncertainty in $k_{1}$ high. Similar conclusions were drawn by Tóth et al. When dissociation of $\mathrm{Eu}(\mathrm{DOTA})^{-}$complex was studied. ${ }^{8}$ According to Tóth et al., the unity term can be neglected in the denominator when working at high $\mathrm{H}^{+}$ion concentrations so eqn. 13 simplifies to eqn. 14 :

$$
k_{d} \approx \frac{k_{2} K_{2}\left[H^{+}\right]}{1+K_{2}\left[H^{+}\right]}
$$

Fitting $k_{d}$ data collected in the range of $1.0-3.12 \mathrm{M} \mathrm{H}^{+}$ion concentrations to eqn. 14 gave $k_{2}=9.54 \pm 0.18 \times 10^{-4} \mathrm{~s}^{-1}$ and $\mathrm{K}_{2}=0.67 \pm 0.03 \mathrm{M}^{-1}$. These data indicate that the dissociation of $\mathrm{Yb}$ $\left(\mathrm{H}_{2} \text { PCTA }\right)^{2+}$ at high acid concentration occurs mainly through formation and dissociation of diprotonated complex (from $\mathrm{Yb}(\mathrm{HPCTA})^{+}$) as a result of the shift of the rate controlling step. Comparing these data to the constants obtained by Kumar et al. for $\operatorname{Gd}(\mathrm{DO} 3 \mathrm{~A}) k_{1}=4.0 \times 10^{-4}$ $\mathrm{s}^{-1}, k_{2}=1.93 \times 10^{-2} \mathrm{~s}^{-1}, \mathrm{~K}_{2}=1.3 \mathrm{M}^{-1}$ and for $\mathrm{Lu}(\mathrm{DO} 3 \mathrm{~A})$ and $k_{2}=3.6 \times 10^{-3} \mathrm{~s}^{-1}$ and $\mathrm{K}_{2}=7.7$ $\mathrm{M}^{-1.35}$ it can be concluded that the rate of direct dissociation of the protonated complex, $\mathrm{Yb}$ (HPCTA $)^{+}$, is similar to the one found for $\mathrm{Gd}(\mathrm{DO} 3 \mathrm{~A})$ but the complex $\mathrm{Yb}(\mathrm{HPCTA})^{+}$appears to be more resistant to the acid catalyzed dissociation. This can be attributed partially to the difference in the second protonation constants of the ligands (Table 1.). The rate of proton assisted dissociation of the complex $\mathrm{Gd}(\mathrm{DO} 3 \mathrm{MA})$ was found to be very similar. In $0.1 \mathrm{M} \mathrm{NaCl}$ the first two protonation constants are lower somewhat $\left(\log K_{1}{ }^{H}=10.82, \log K_{2}{ }^{H}=8.42\right)$ than the value measured in $0.1 \mathrm{M} \mathrm{Me}_{4} \mathrm{NCl}\left(\log K_{l}{ }^{H}=13.38, \log K_{2}{ }^{H}=9.15\right) .{ }^{41}$ In those cases where a higher concentration of background electrolyte was used, this difference will be even higher and the values will probably be close to the values measured for the ligand PCTA (Table 1.). The rate constants obtained for Gd(DO3MA) are $k_{l}=3.7 \times 10^{-5} \mathrm{~s}^{-1}, k_{2}=5.2 \times 10^{-4} \mathrm{~s}^{-1}, \mathrm{~K}_{2}=5$ $\mathrm{M}^{-1}$, characterizing the direct dissociation, proton catalyzed dissociation of the monoprotonated complex and the protonation constant of the complex, respectively. ${ }^{41}$ The rate of the proton catalyzed dissociation of the monoprotonated complex $\left(k_{2}\right)$ is very close to that found for $\mathrm{Yb}(\mathrm{PCTA})$. It appears that the protonation constants of the ligands are critical when the ligand is chosen for complexation and in vivo use. However, all of our attempts to find a correlation between the first (or sum of the first and second) protonation constants of the ligands and the rate of the acid catalyzed dissociation of the complexes failed. This is possibly due to the large errors in the kinetic data, differences in the ionic media used for the evaluation of equilibrium (protonation constants determination) and kinetic data and differences in the dissociation mechanisms of the complexes.

\section{Conclusions}

The thermodynamic stability of a few $\operatorname{Ln}$ (PCTA) complexes were determined and found to be in the range from 18.15 for $\mathrm{Ce}(\mathrm{PCTA})$ to 20.63 for $\mathrm{Yb}(\mathrm{PCTA})$. The trend of the stability constants is similar to that of the $\operatorname{Ln}(\mathrm{NOTA})$ and/or $\operatorname{Ln}(\mathrm{DOTA})^{-}$complexes involving a large 
increase at the beginning of the series, practically constant values for $\operatorname{Ln}(\mathrm{III})$ ions in the middle of the series, and a slight increase of the stability at the end for $\mathrm{Yb}(\mathrm{PCTA})$. The mechanism of complex formation is similar to that reported earlier for DOTA and DOTA derivatives, but formation of $\operatorname{Ln}(\mathrm{PCTA})$ proceeds at least 10 times faster than the corresponding $\operatorname{Ln}$ (DOTA) complexes. The formation rates increase with decreasing lanthanide size and there is an order of magnitude difference between the $k_{O H}$ values for $\mathrm{Ce}$ (PCTA) and $\mathrm{Yb}$ (PCTA). According to our studies, $\operatorname{Ln}(\mathrm{PCTA})$ complexes have the fastest formation rates among all 9- to 14membered tri- or tetraazamacrocyle ligands studied so far. The fast formation kinetics can be attributed at least in a part to pre-organization of the ligand by the pyridine ring.

Spontaneous dissociation of the $\operatorname{Ln}(\mathrm{PCTA})$ complexes was too slow to be evaluated here but acid catalyzed dissociation of $\operatorname{Ln}(\mathrm{PCTA})$ complexes occurred at about an order of magnitude faster than that for the corresponding $\operatorname{Ln}(\mathrm{DOTA})^{-}$complexes. The acid catalyzed dissociation rates decreasing with decreasing $\mathrm{Ln}(\mathrm{III})$ ion size. While $\mathrm{Ln}$ (PCTA) complexes dissociate somewhat faster than Ln(DOTA) complexes in acid, these complexes are still kinetically quite inert at physiological $\mathrm{pH}$ values and appear to have sufficient kinetic inertness for in vivo applications.

The current study may have implications for the future design of complexing agents that have both favorably fast formation kinetics and favorable kinetic inertness toward dissociation.

Based on the present thermodynamic and kinetic data, PCTA seems to be an attractive ligand for constructing radiopharmaceutical applications that require rapid formation kinetics.

\section{Supplementary Material}

Refer to Web version on PubMed Central for supplementary material.

\section{Acknowledgements}

This paper is dedicated to Professor Ernő Brücher on the occassion of his 70th birthday. This work was supported in part by grants from the National Institutes of Health (CA-115531 and RR-02584) and the Robert A. Welch Foundation (AT-584). This work was carried out in the framework of the EU COST Action D18.

\section{References}

1. (a) Caravan P, Ellison JJ, McMurry TJ, Lauffer RB. Chem Rev 1999;99:2293. [PubMed: 11749483] (b) Lauffer RB. Chem Rev 1987;87:901. (c) Volkert WA, Hoffman TJ. Chem Rev 1999;99:2269. [PubMed: 11749482]

2. Guo ZJ, Sadler PJ. Angew Chem Int Edit 1999;38:1513.

3. (a) Brücher E. Topic in Current Chemistry 2002;221:104.Brücher, E.; Sherry, AD. Stability and Toxicity of Contrast Agents. In: Tóth, É.; Merbach, AE., editors. The Chemistry of Contrast Agents in Medical Magnetic Resonance Imaging. Wiley; Chichester: 2001. p. 243

4. Kozak RW, Raubitschek A, Mirzadeh S, Brechbiel MW, Junghaus R, Ganshow OA, Waldmann TA. Cancer Res 1989;39:2639. [PubMed: 2785435]

5. Brücher E, Sherry AD. Inorg Chem 1990;29:1555.

6. Brücher E, Cortes S, Chavez F, Sherry AD. Inorg Chem 1991;30:2092.

7. Brücher E, Laurenczy G, Makra Z. Inorg Chim Acta 1987;139:141.

8. Tóth É, Brücher E, Lázár I, Tóth I. Inorg Chem 1994;33:4070.

9. Burai L, Fábián I, Király R, Szilágyi E, Brücher E. J Chem Soc Dalton Trans 1998:243.

10. Kumar K, Tweedle MF. Inorg Chem 1993;32:4193.

11. Kumar K, Jin TZ, Wang XY, Desreux JF, Tweedle MF. Inorg Chem 1994;33:3823.

12. Wu SL, Horrocks WD. Inorg Chem 1995;34:3724.

13. Balogh E, Tripier R, Ruloff R, Tóth É. J Chem Soc Dalton Trans 2005:1058. 
14. Wang X, Tianzhu J, Comblin V, Lopez-Mut A, Merciny E, Desreux JF. Inorg Chem 1992;31:1095.

15. Stetter H, Frank W, Mertens R. Tetrahedron 1981;37:767.

16. Aime S, Botta M, Crich SG, Giovenzana GB, Jommi G, Pagliarin R, Sisti M. Inorg Chem 1997;36:2992-3000. [PubMed: 11669949]

17. Siaugue JM, Segat-Dioury F, Favre-Reguillon A, Madic C, Foos J, Guy A. Tetrahedron Lett 2000;41:7443.

18. Siaugue JM, Segat-Dioury F, Sylvestre I, Favre-Reguillon A, Foos J, Madic C, Guy A. Tetrahedron 2001;57:4713.

19. Siaugue JM, Segat-Dioury F, Favre-Reguillon A, Wintgens V, Madic C, Foos J, Guy A. J Photochem Photobiol A 2003;156:23.

20. Kim WD, Kiefer GE, Maton F, McMillan K, Muller RN, Sherry AD. Inorg Chem 1995;34:2233.

21. Aime S, Botta M, Crich SG, Giovenzana G, Pagliarin R, Sisti M, Terreno E. Magn Reson Chem 1998;36:S200.

22. Alexander V. Chem Rev 1995;95:273.

23. Delgado R, Quintino S, Teixeira M, Zhang A. J Chem Soc Dalton Trans 1997:55.

24. Delgado R, Figueira MD, Quintino S. Talanta 1997;45:451. [PubMed: 18967026]

25. Siaugue JM, Favre-Reguillon A, Dioury F, Plancque G, Foos J, Madic C, Moulin C, Guy A. Eur J Inorg Chem 2003:2834.

26. Schwarzenbach, G.; Flaschka, H. Complexometric Titrations. 2nd English. Barnes and Noble; New York: 1969. p. 490

27. Irving HM, Miles MG, Pettit LD. Anal Chim Acta 1967;38:475.

28. Zékány, L.; Nagypál, I. Computational Methods for Determination of Formation Constants. Legett, DJ., editor. Plenum Press; New York: 1985.

29. Beck, MT.; Nagypál, I. Chemistry of Complex Equilibria. Ellis Horwood; Chichester: 1990. p. 348-350.

30. Delgado R, Sun Y, Motekaitis RJ, Martell AE. Inorg Chem 1993;32:3320.

31. Bevilacqua A, Gelb RI, Hebard WB, Zompa LJ. Inorg Chem 1986;26:2699.

32. Chaves S, Delgado R, Fraústo Da Silva JJR. Talanta 1992;39:249. [PubMed: 18965370]

33. Delgado R, Fraústo da Silva JJR. Talanta 1982;29:815. [PubMed: 18963244]

34. Cacheris WP, Nickel SK, Sherry AD. Inorg Chem 1987;26:958.

35. Kumar K, Chang CA, Tweedle MF. Inorg Chem 1993;32:587.

36. Kumar K, Chang CA, Francesconi LC, Dischino DD, Malley MF, Gougoutas JZ, Tweedle MF. Inorg Chem 1994;33:3567.

37. Kasprzyk SP, Wilkins RG. Inorg Chem 1982;21:3349.

38. Martell, AE.; Smith, RM. Critical Stability Constants. 3. Plenum; New York: 1977.

39. Szilágyi E, Tóth É, Kovács Z, Platzek J, Radüchel B, Brücher E. Inorg Chim Acta 2000;298:226.

40. Chang CA, Liu YL, Chen CY, Chou XM. Inorg Chem 2001;40:3448. [PubMed: 11421691]

41. Kang SI, Ranganathan RS, Emswiler JE, Kumar K, Gougoutas JZ, Malley MF, Tweedle MF. Inorg Chem 1993;32:2912. 


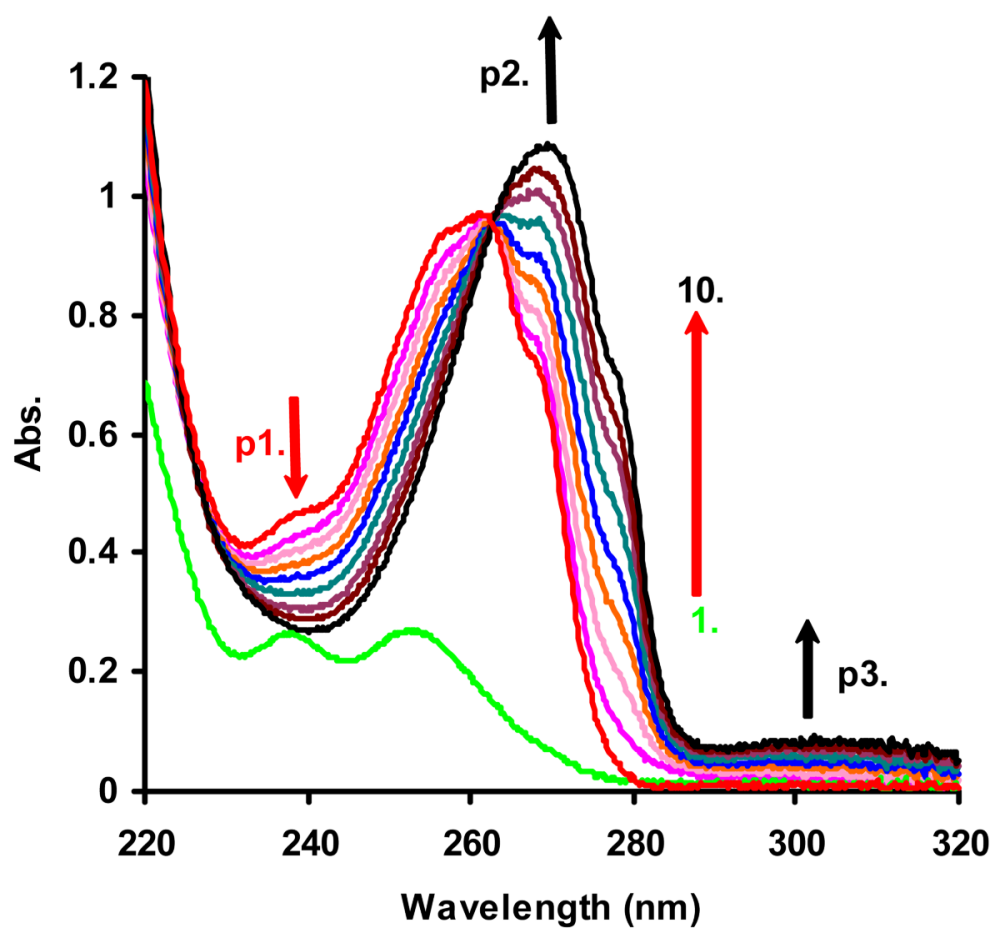

Figure 1.

Absorbance changes in UV region recorded for formation of $\mathrm{Ce}(\mathrm{PCTA})$ after mixing equimolar amounts of $\mathrm{Ce}^{3+}$ and PCTA at $\mathrm{pH}=4.07\left(\mathrm{C}_{\mathrm{Ce}(\mathrm{PCTA})}=0.2 \mathrm{mM}, 1.0 \mathrm{M} \mathrm{KCl}, 0.05 \mathrm{M} \mathrm{DMP}\right)$; each curve corresponds to 1) $\mathrm{Ce}^{3+}$ alone in DMP buffer, 2) immediately after mixing $\mathrm{Ce}^{3+}$ with PCTA ("0" $\mathrm{min}$ ), 3) after $1 \mathrm{~min}, 4$ ) after $3 \mathrm{~min}, 5$ ) after $6 \mathrm{~min}, 6$ ) after $10 \mathrm{~min}, 7$ ) after $19 \mathrm{~min}$, 8) after $38 \mathrm{~min}, 9$ ) after $70 \mathrm{~min}$, and 10) at equilibrium. 

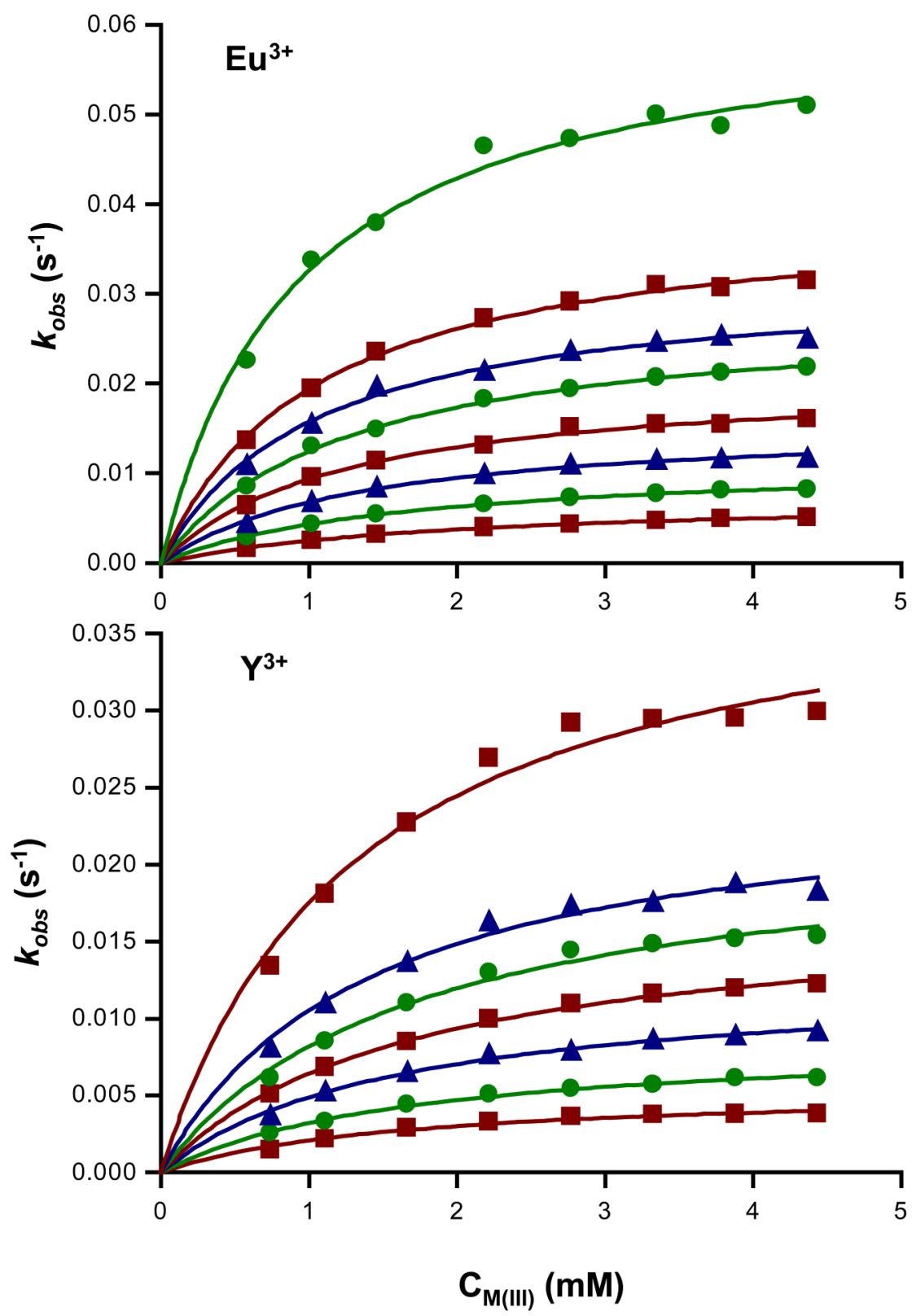

Figure 2.

Pseudo-first-order rate constants, $k_{o b s}$ as a function of $\mathrm{M}(\mathrm{III})$ ion concentration at different $\mathrm{pH}$ in the formation reaction of some $\mathrm{M}$ (PCTA) complexes ( $\mathrm{pH}$ readings from top to bottom are: 4.40, 4.21, 4.14, 4.07, 3.97, 3.86, 3.72 and 3.56 for Eu(PCTA) and 4.40, 4.21, 4.14, 4.07, 3.97, 3.86 and 3.72 for $\mathrm{Y}(\mathrm{PCTA})$ ). 


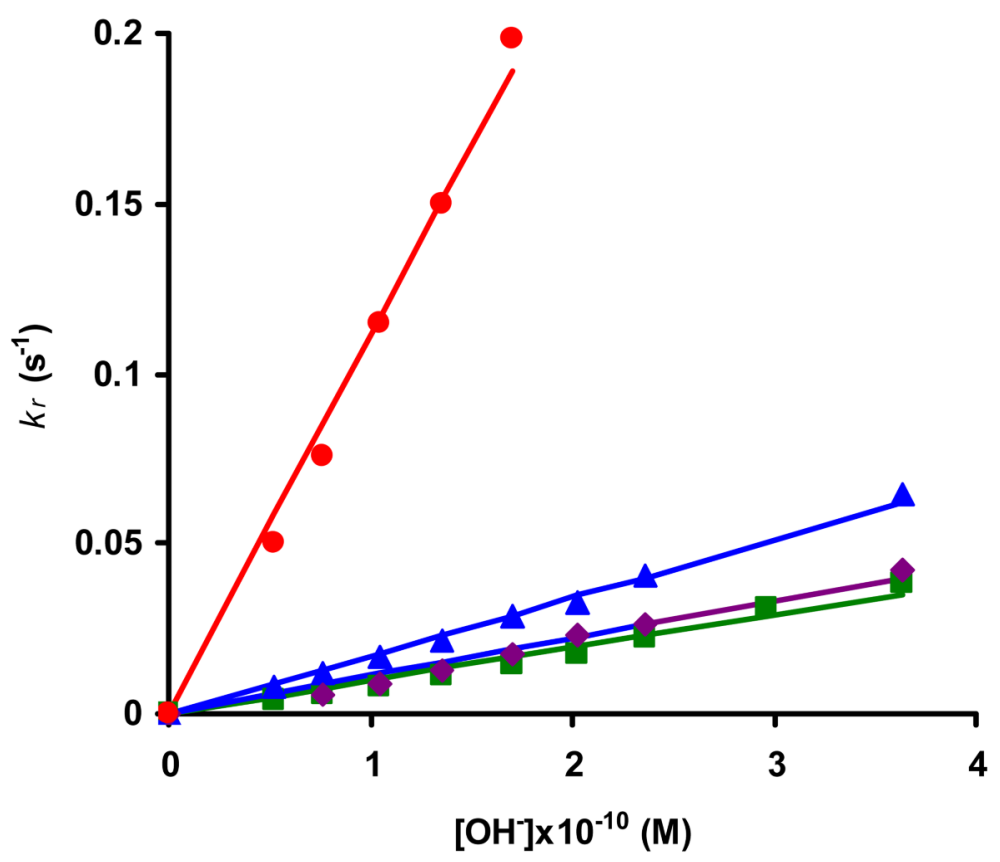

Figure 3.

Formation rates of $\mathrm{M}(\mathrm{PCTA})$ complexes vs. $\mathrm{OH}^{-}$ion concentration for $\mathrm{Ce}$ (green squares), Eu (blue triangles), $\mathrm{Y}$ (violet diamonds), and $\mathrm{Yb}$ (red circles) $\left(\mathrm{I}=1.0 \mathrm{M} \mathrm{KCl}, \mathrm{t}=25^{\circ} \mathrm{C}\right)$. 


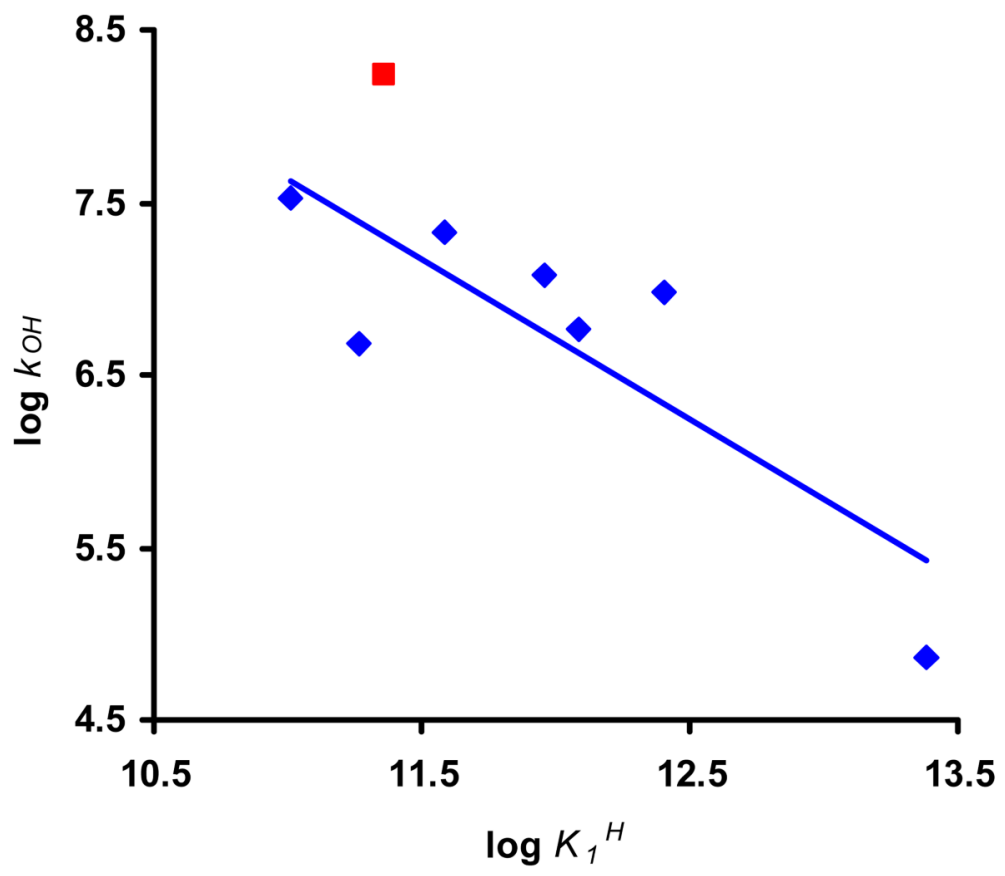

Figure 4.

Correlation of $\log k_{O H}$ obtained for some 12 membered macrocyclic ligands with the first protonation constant $\left(\log K_{l}{ }^{H}\right)$ of the ligand. 


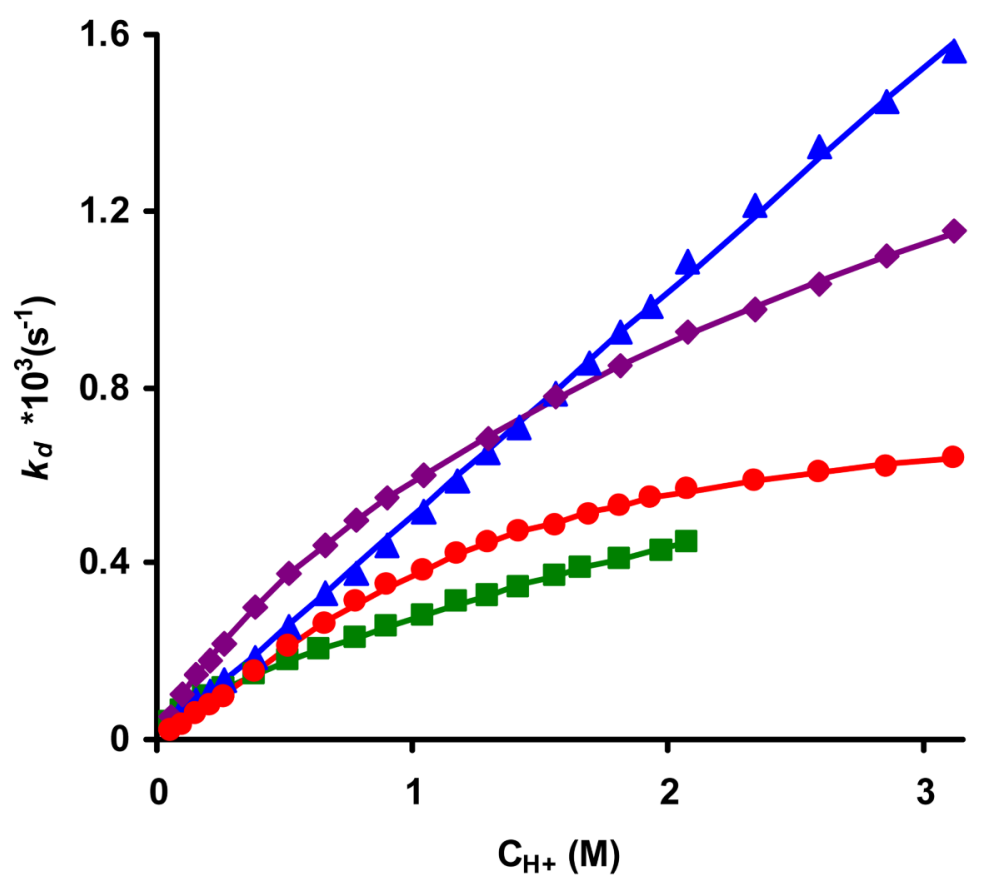

Figure 5.

Dissociation rates $\left(k_{d}\right)$ for CePCTA (green squares), EuPCTA (blue triangles), YPCTA (violet diamonds) and YbPCTA (red circles) as a function of $\mathrm{H}^{+}$concentration. 


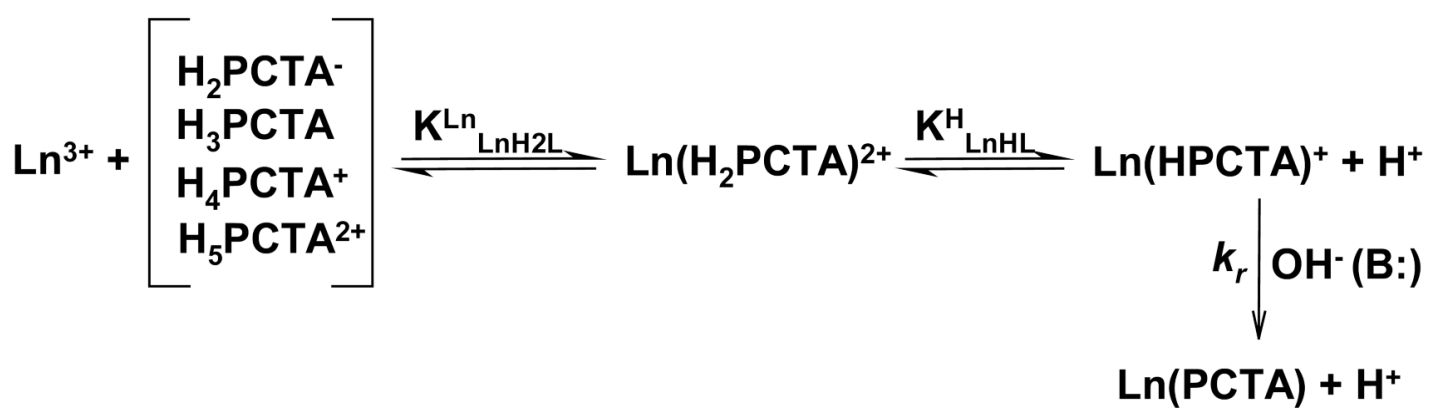

Scheme 1.

Suggested, the most probable formation scheme of $\mathrm{Ln}$ (PCTA) complexes. 


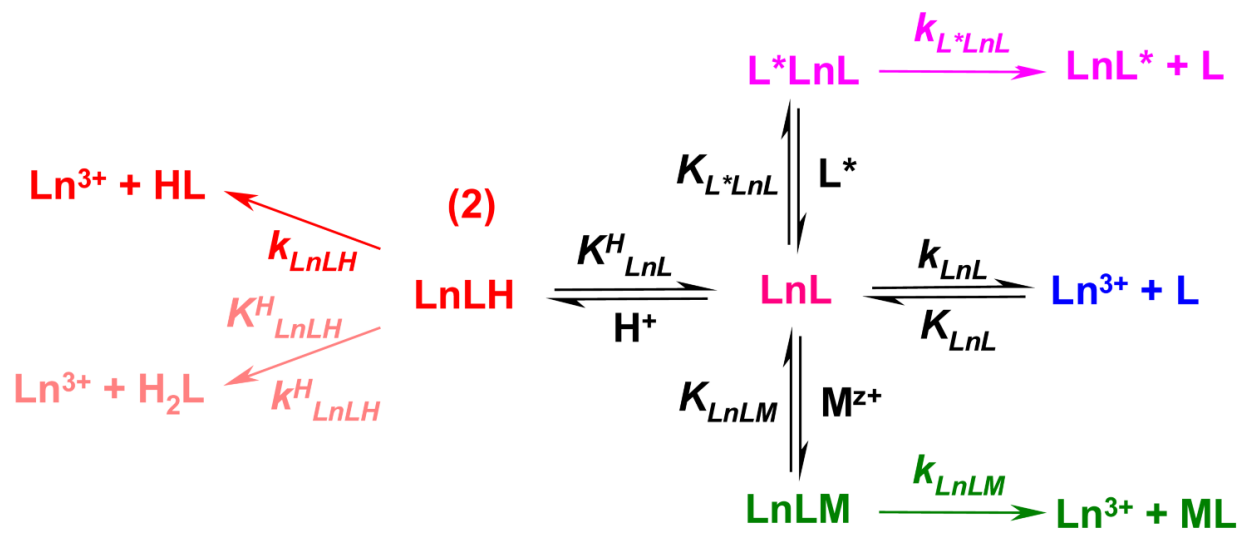

Scheme 2.

Dissociation of LnL complexes. 


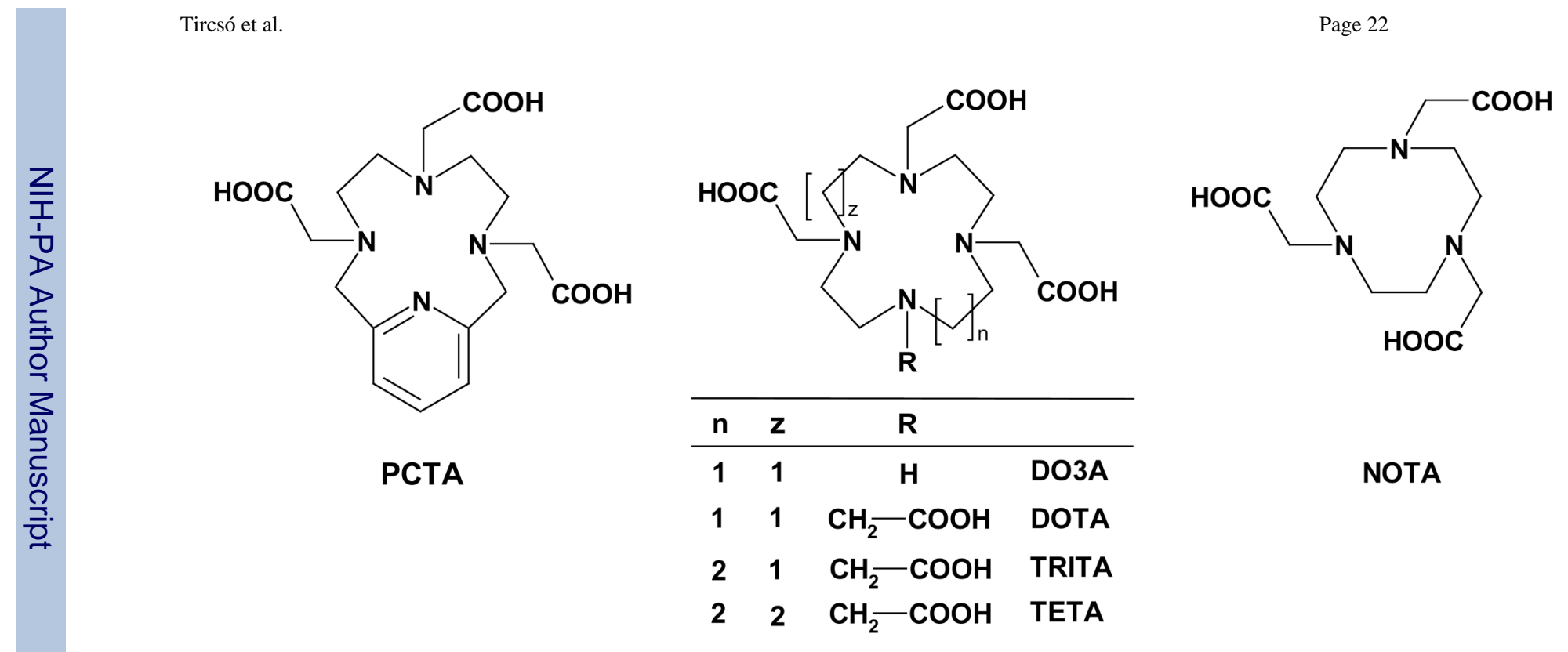

Chart 1.

Structure of the ligand studied and ligands used for the comparison in the work. 


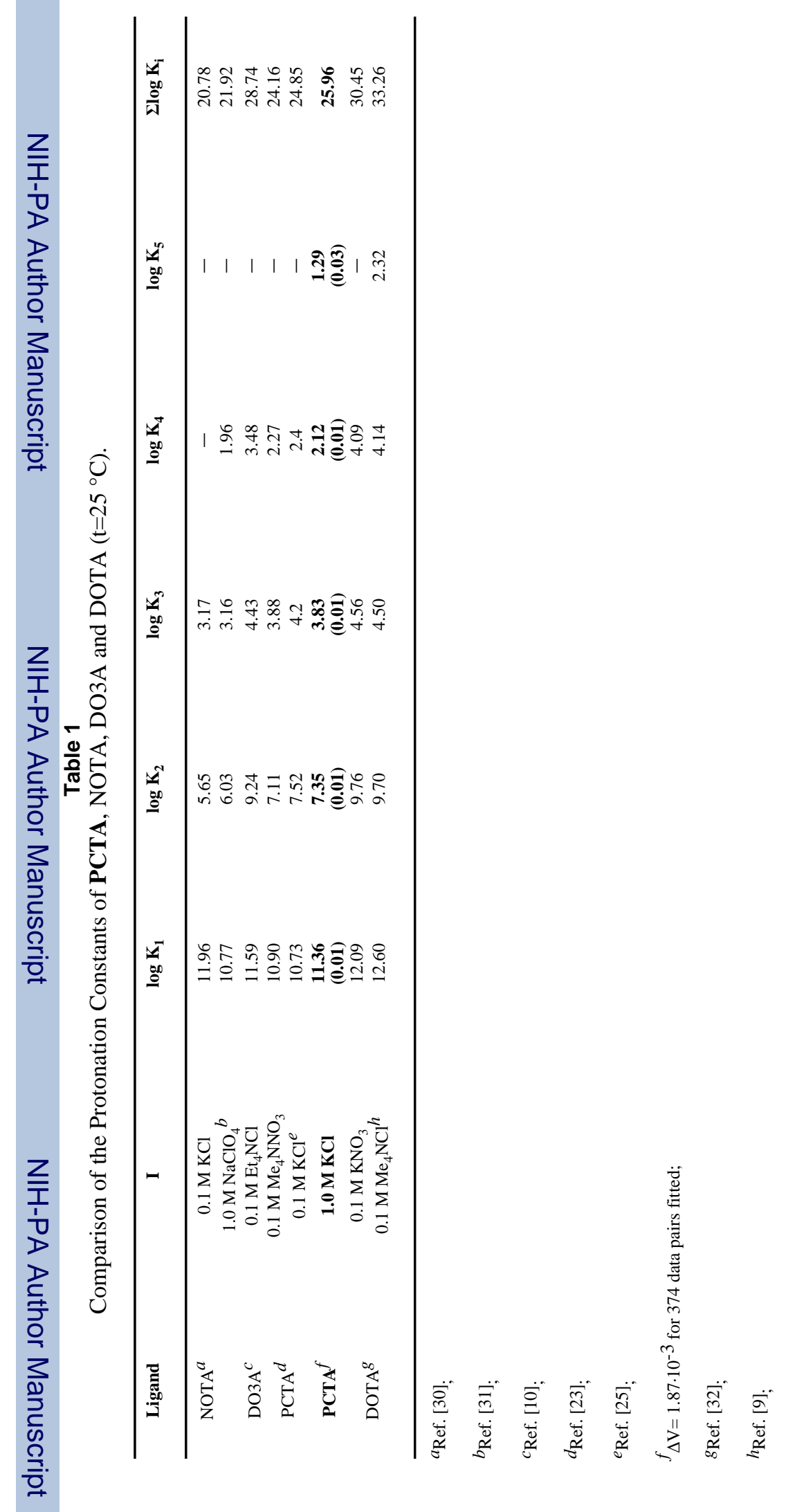


㲴

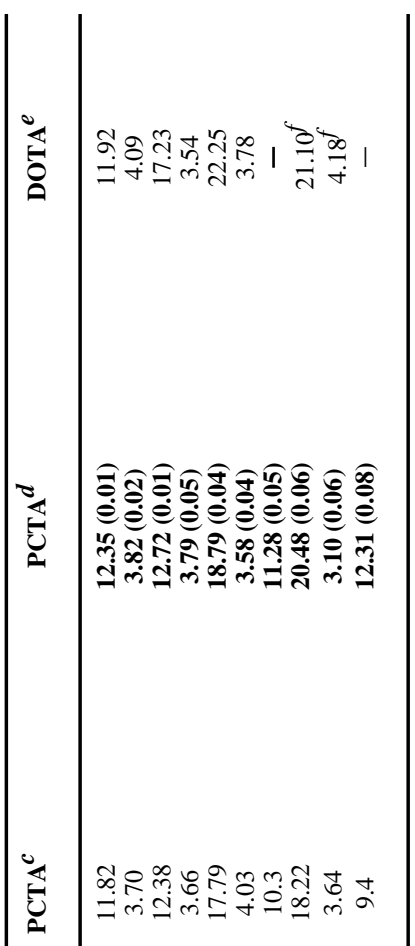

$z$

辛

$>\sim$

$\rightarrow \frac{0}{\circ}$

우 


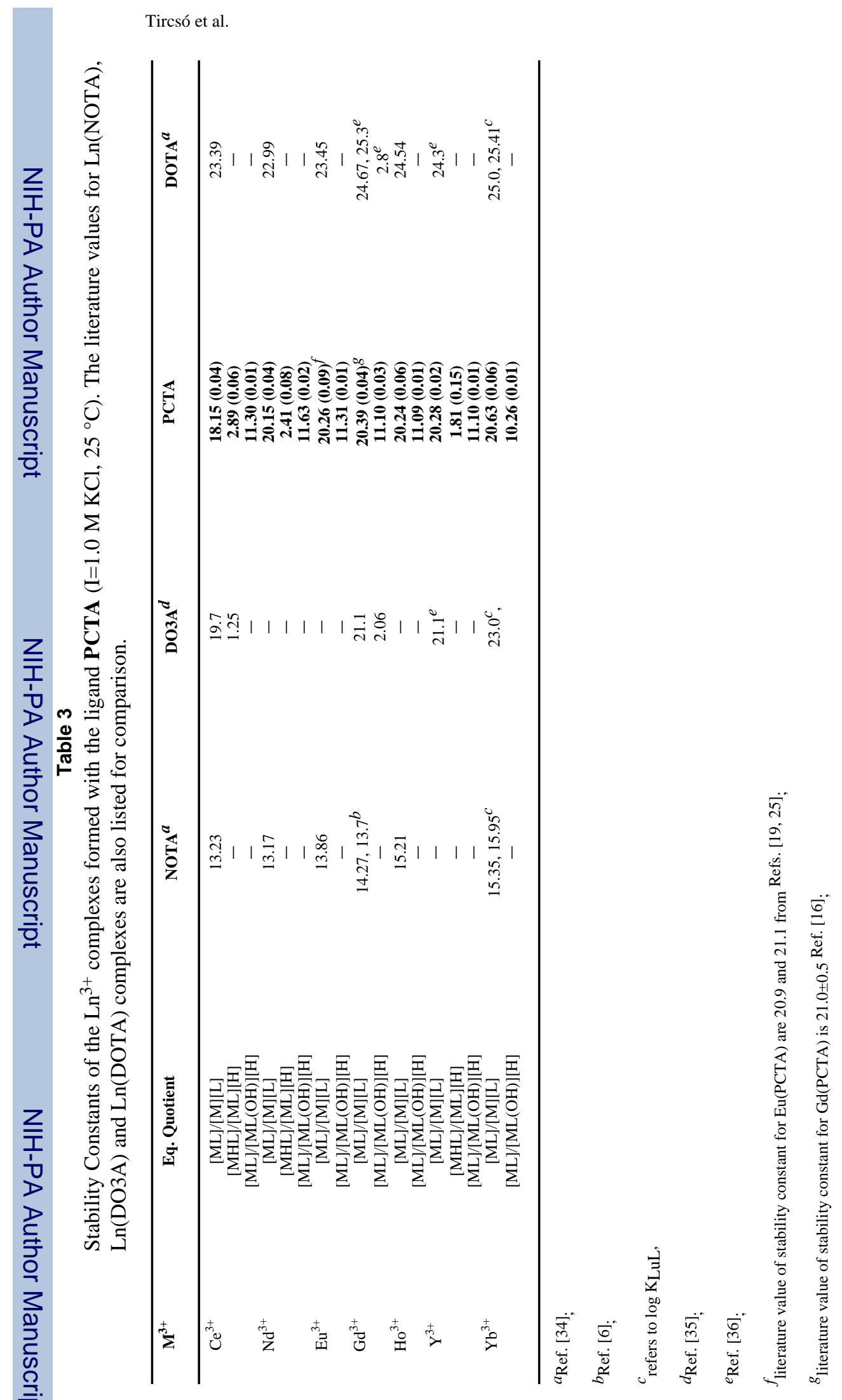

Page 25 
Table 4

Rate constants, $k_{O H}$ characterizing the rearrangements of Ce(PCTA), Eu(PCTA), Y(PCTA) and Yb(PCTA) complexes $\left(\mathrm{I}=1.0 \mathrm{M} \mathrm{KCl}, 25{ }^{\circ} \mathrm{C}\right)$ compared it to literature data for complexes formed with macrocyclic ligands.

\begin{tabular}{|c|c|c|c|c|}
\hline & & \multicolumn{2}{|c|}{$k_{O H}\left(M^{-1} s^{-1}\right)$} & \multirow[b]{2}{*}{$\mathbf{Y b}^{3+}$} \\
\hline & $\mathrm{Ce}^{3+}$ & $\mathbf{E u}^{3+}$ & $\mathrm{Gd}^{3+}$ & \\
\hline NOTA $^{a}$ & $6.3 \times 10^{7}$ & - & $7.1 \times 10^{7}$ & $5.5 \times 10^{7}$ \\
\hline $\mathrm{DO}_{3} \mathrm{~A}^{b}$ & - & - & $2.1 \times 10^{7}$ & - \\
\hline PCTA & $(9.68 \pm 0.34) \times 10^{7}$ & $(1.74 \pm 0.03) \times 10^{8}$ & $(1.13 \pm 0.03) \times 10^{8 c}$ & $(1.11 \pm 0.03) \times 10^{9}$ \\
\hline DOTA $^{d}$ & $3.5 \times 10^{6}, 1.16 \times 10^{6 e}, 2.7 \times 10^{6 f}$ & $1.1 \times 10^{7}, 7.2 \times 10^{6 b}$ & $5.9 \times 10^{6 b}$ & $4.1 \times 10^{7}, 9.3 \times 10^{7 f}$ \\
\hline TRITA $^{g}$ & $6.9 \times 10^{6}$ & - & $2.6 \times 10^{7}$ & $5.0 \times 10^{7}$ \\
\hline TETA $^{e}$ & $5.58 \times 10^{6}$ & - & - & - \\
\hline
\end{tabular}

${ }^{a}$ Ref. [5];

$b_{\text {Ref. [12]; }}$

$c_{\text {refers to } \mathrm{Y}(\mathrm{PCTA}) \text {; }}$

${ }^{d}$ Ref. [8];

${ }^{e}$ Ref. [40], for Ce(TETA) ${ }^{-}$term with second order dependence on $\mathrm{OH}^{-}$ion concentration was observed, too;

$f_{\text {Ref. [9]; }}$

$g_{\text {Ref. [13]; }}$ 


\section{Table 5}

Rates of dissociation for $\mathrm{Ce}(\mathrm{PCTA}), \mathrm{Eu}(\mathrm{PCTA}), \mathrm{Y}(\mathrm{PCTA})$ and $\mathrm{Yb}(\mathrm{PCTA})$ complexes (I=1.0 $\left.\mathrm{M} \mathrm{KCl}, 25^{\circ} \mathrm{C}\right)$, data for some other complexes formed with macrocyclic ligands are also listed for comparison.

\begin{tabular}{|c|c|c|c|c|}
\hline Ligand & $\mathbf{L n}^{3+}$ & $\mathrm{Ce}^{3+}$ & $\mathrm{Gd}^{3+}$ & $\mathbf{Y b}^{3+}$ \\
\hline NOTA & $\begin{array}{c}k_{0} \mathrm{~s}^{-1} \\
k_{l} \mathrm{M}^{-1} \mathrm{~s}^{-1}\end{array}$ & $\begin{array}{l}2.5 \times 10^{-5} \\
4.3 \times 10^{-2}\end{array}$ & $\begin{array}{l}8.3 \times 10^{-6} \\
2.3 \times 10^{-2}\end{array}$ & $\begin{array}{l}2.7 \cdot 10^{-6 a} \\
1.6 \cdot 10^{-3 a}\end{array}$ \\
\hline DO3A & $\begin{array}{c}k_{0} \mathrm{~s}^{-1} \\
k_{l} \mathrm{M}^{-1} \mathrm{~s}^{-1}\end{array}$ & $\begin{array}{c}1.8 \times 10^{-3} \\
1.12 \times 10^{-1}\end{array}$ & $\begin{array}{c}4.0 \times 10^{-4} \\
2.51 \times 10^{-2 b}\end{array}$ & $\begin{array}{c}- \\
2.77 \times 10^{-2 b}\end{array}$ \\
\hline PCTA & $\begin{array}{c}k_{0} \mathbf{s}^{-1} \\
k_{1} \mathbf{M}^{-1} \mathbf{s}^{-1} \\
\left(k_{1} \times \mathbf{K}_{1}\right) \mathbf{M}^{-1} \mathbf{s}^{-1} d \\
\left(k_{2} \times \mathbf{K}_{1} \times \mathbf{K}_{2}\right) \mathbf{M}^{-2} \mathbf{s}^{-1 d} \\
\mathbf{K}^{\mathbf{1 H}} \\
\mathbf{K}^{\mathbf{2 H}}\end{array}$ & $\begin{array}{c}\overline{-}^{c} \\
- \\
9.61 \times 10^{-4} \\
2.07 \times 10^{-3} \\
8.90 \pm 0.87 \\
0.13 \pm 0.02\end{array}$ & $\begin{array}{c}-^{c} \\
(\mathbf{5 . 0 8} \pm \mathbf{0 . 0 4}) \times 10^{-4 e} \\
1.07 \times \mathbf{1 0} 0^{-3 f} \\
\mathbf{6 . 3 2} \times \mathbf{1 0} 0^{-4 f} \\
\mathbf{1 . 7 2} \pm \mathbf{0 . 1 7} \\
0.11 \pm \mathbf{0 . 0 3}\end{array}$ & $\begin{array}{c}-^{c} \\
(\mathbf{3 . 8 7} \pm \mathbf{0 . 0 4}) \times 10^{-4} g \\
2.80 \times 10^{-4} \\
8.85 \times 10^{-4} \\
0.99 \pm 0.16 \\
1.12 \pm 0.10\end{array}$ \\
\hline DOTA & $\begin{array}{c}k_{0} \mathrm{~s}^{-1} \\
k_{1} \mathrm{M}^{-1} \mathrm{~s}^{-1}\end{array}$ & $\begin{array}{c}- \\
8 \times 10^{-4 h}\end{array}$ & $\begin{array}{c}5 \times 10^{-10 i} \\
2 \times 10^{-6 i} 1.4 \times 10^{-5 j}\end{array}$ & $\begin{array}{l}- \\
-\end{array}$ \\
\hline
\end{tabular}

$a_{\text {refers to } \operatorname{Er}(\mathrm{NOTA}) \text {; }}$

$b_{\text {calculated from data in }}$ Ref. [35] for the dissociation of $\mathrm{Lu}\left(\mathrm{H}_{2} \mathrm{DO} 3 \mathrm{~A}\right)$;

$c_{\text {fixed to zero (see text) }}$

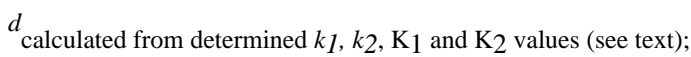

$e_{\text {refers to } \mathrm{Eu}(\mathrm{PCTA}) \text {; }}$

$f_{\text {refers to } \mathrm{Y}(\mathrm{PCTA}) \text {; }}$

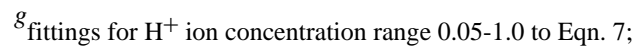

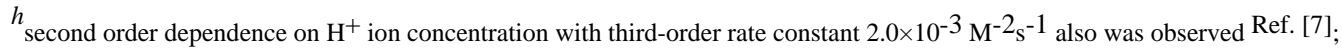

${ }^{i}$ Ref. [9];

${ }_{\text {calculated for } \mathrm{Eu}(\mathrm{DOTA})^{-} \text {from }}{ }^{\text {Ref. }}\left[{ }^{8}\right] \mathrm{k} 2$ also can be calculated $=1.04 \times 10^{-3} \mathrm{M}^{-2} \mathrm{~s}^{-1}$ with the use of $k 1=1 \times 10^{-6} \mathrm{~s}^{-1}$ and $k_{2}=6.2 \times 10^{-4} \mathrm{~s}^{-1}$ and protonation constants $\mathrm{K}_{1}=14 \mathrm{M}^{-1}$ and $\mathrm{K}_{2}=0.12 \mathrm{M}^{-1}$; 